\title{
Perioperative nonspecific histamine release: a new classification by aetiological mechanisms and evaluation of their clinical relevance
}

\author{
Libération périopératoire non spécifique d'histamine: \\ causes anesthésiques et non anesthésiques
}

\author{
D. DUDA * W. LORENZ ${ }^{\star *}$, H. MENKE ${ }^{\star \star *}$, B. STINNER ${ }^{+}$, C. HASSE ${ }^{+}$, C. NIES ${ }^{+}, \mathrm{U}^{*} \mathrm{SCHÄFER}^{+}$, \\ H. SITTER **, T. JUNGINGER ${ }^{\star \star \star}$, M. ROTHMUND ${ }^{+}$, A. DOENICKE ${ }^{\square}$, W. DICK ${ }^{\star}$ \\ * Clinic of Anaesthesiology, University of Mainz \\ * Institute of Theoretical Surgery, University of Marburg \\ ** Clinic of General Surgery, University of Mainz \\ + Clinic of General Surgery, University of Marburg \\ "Institute of Anaesthesiology, Ludwig-Maximilian University of Munich (Germany).
}

\begin{abstract}
RÉSUMÉ : Les auteurs ont réalisé quatre études prospectives dans le but d'étudier les différents facteurs responsables de la libération d'histamine dans la période périopératoire. Les réactions allergiques vraies et les réactions pseudo-allergiques ne sont pas seules en cause. De nombreux autres mécanismes d'histaminolibération sont suggérés : mécanismes neuroendocriniens, libération consécutive à des stimuli nociceptifs, facteurs cytotoxiques consécutifs au traumatisme tissulaire de l'acte chirurgical et libération induite par les cytokines. Ces mécanismes ont été mis en évidence dans deux études prospectives étudiant, l'une des patients lors d'une gastroscopie réalisée sans prémédication et l'autre, des patients bénéficiant d'une cholécystectomie percœlioscopique. Dans une autre étude, une histaminolibération par mécanisme pseudoallergique a été notée immédiatement après l'induction anesthésique chez un nombre important de patients opérés pour divers actes de chirurgie générale. Dans ces deux cas, l'histaminolibération est indésirable car elle est à l'origine de symptômes de gravité variable. Les signes cliniques sont surtout cardiovasculaires et respiratoires alors que les signes cutanés sont souvent absents. Les auteurs considèrent que dans la période périopératoire la libération d'histamine est indésirable dans certains cas mais dans d'autres elle n'a pas de conséquences néfastes, pouvant même être bénéfique. Une réévaluation des signes cliniques d'histaminolibération est nécessaire puisque les études ont montré que des concentrations plasmatiques de $12 \mathrm{ng} \cdot \mathrm{ml}^{-1}$ d'histamine souvent ne s'accompagnaient d'aucun signe cutané. Ainsi une histaminolibération non spécifique n'est, le plus souvent, pas reconnue comme cause d'une hypotension artérielle périopératoire en raison du manque de spécificité de ce symptôme. Des études ultérieures doivent préciser le rôle des médicaments antihistaminiques (anti- $\mathrm{H}_{1}$ et anti- $\mathrm{H}_{2}$, doses, choix des patients, moment de l'administration) dans la prévention de l'histaminolibération périopératoire.
\end{abstract}

\section{CLASSIFICATION OF PERIOPERATIVE HISTAMINE RELEASE}

In the last conference on prevention of perianaesthetic anaphylactoid reactions, Nancy, 1984 [52], a whole series of mechanisms for nonspecific histamine release was not mentioned at all [62]. Surgical trauma was included, but only one reference could be given at this time [93] and did not challenge the general opinion over 50 years that " histamine does not play an impor-

Presented at the meeting "New Trends in Anaphylactoid Risk in Anaesthesia ». Nancy (France), 11-12 June 1992. tant role in major injury or traumatic shock » $[1$, 31].

In this conference [54], however, a considerable increase of knowledge has to be reported which creates new hypotheses on functions of histamine in clinical epidemiology (fig. 1). A new classification has to be found which does not only alter aetiology, but also pathogenesis and disease manifestations, especially in the perioperative and postoperative period.

Tirés à part: D. Duda. 


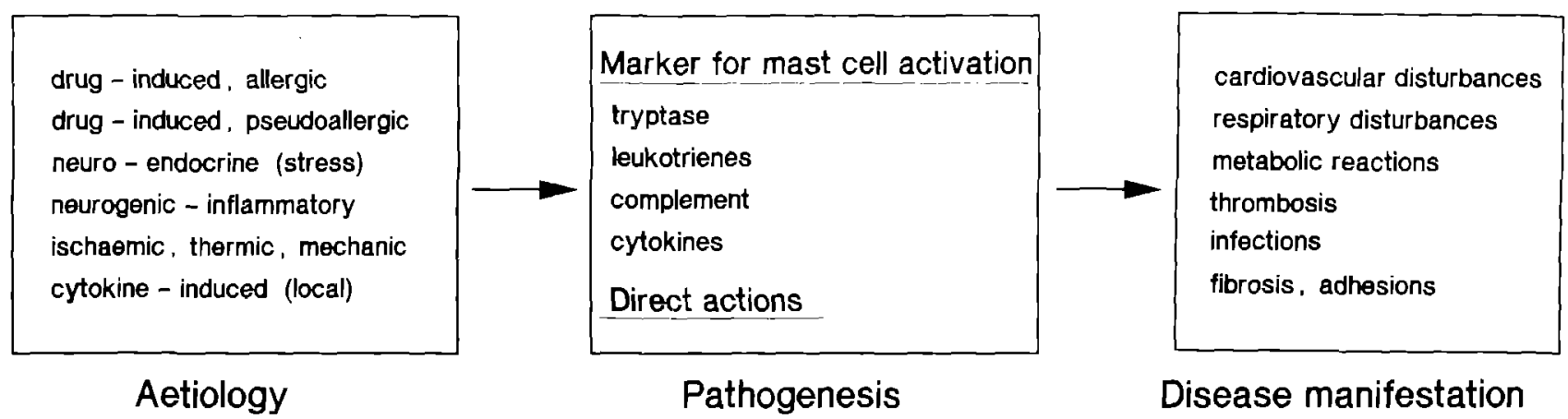

Fig. 1. - Classification of histamine release in the perioperative and postoperative period by means of its role in clinical epidemiology.

\section{Aetiology}

In aetiology, as the first part of the causality chain, drug-induced specific allergic reactions involving antigen-antibodies ( $\mathrm{IgE}, \mathrm{IgG}_{4}$ ) in early phase and antigen-sensitized cells (T-cell) in late phase have no longer to be emphasized in anaesthesiology. They are now a classical issue in textbooks and guides $[53,56,109]$ and the objective of persistent research in many groups around the world [54]. The 3 classes of substances mostly investigated include muscle relaxants, analgesics and hypnotics whereas plasma substitutes and contrast media obtain less attention now than in the 70 -ies and 80-ies.

Drug-induced nonspecific or pseudoallergic reactions resemble allergic reactions either in parts of the pathogenetic pathway or in disease manifestations, but do not include antigen-antibody reactions or antigen-sensitized cell reactions in their aetiology (exposition) [15]. This does not exclude them as risk factors. Pseudoallergic reactions occur following administration of the same drugs which also induce specific reactions. This finding explains some of the competition which can be observed between groups working more on the immunological or toxicological aspects of the adverse drug reactions $[17,67]$. However, there are at least 100 drugs used in anaesthesia and surgery which produce pseudoallergic reactions $[72,83]$ and these are therefore also classical issues in anaesthesiology and intensive care medicine.

Histamine release induced by neuro-endocrine stimuli (e.g. the central effects of stress) or by neuro-inflammatory stimuli (e.g. the peripheral effects of stimulating pain fibers), is new in this classification. The reason for such an enlargement of the spectrum is, indeed, the considerable research in this field during the last 10 years and the demonstration of increased plasma histamine levels in the perioperative period which have to be considered as an in vivo parameter for such mechanisms in clinical conditions. The physiological pathways of the stress response include both the central and peripheral nervous systems. The nociceptive signal is transmitted by small myeli-

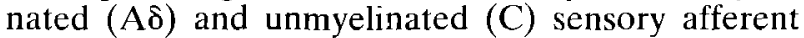
fibers to the central nervous system [42], but also other stimuli including anxiety, starvation, heat loss, acidosis, haemorrhage are involved in release mechanisms of the endocrine-metabolic response to trauma [42]. Even opioids given for pain relief in anaesthesia can produce a large spectrum of the responses typically associated with stress to anaesthesia and surgery including histamine release [105]. This rises the provocative question whether perioperative stress is a real surgical phenomenon or merely a drug-induced effect [105].

The role of histamine in stress is best described by its participation in the neuroendocrine regulation of pituitary hormone secretion, but also in the regulation of some peripheral hormones such as the catecholamines [45]. According to KNIGGE and WARBERG [45] histaminergic neurons seem to participate in the mediation of the stress-induced release of ACTH, $\beta$-endorphin, $\alpha$-melanocytestimulating hormone and prolactin, but also of vasopressin, oxytocin, the catecholamines and renin. Histamine release in human subjects during stress will be shown in the following clinical trials. It will be demonstrated by elevated plasma histamine levels which will show pharmacokinetics and clinical symptoms resembling those after i.v. histamine injection [66], and not those of histamine release from mast cells in the tissues after histamine-releasing drugs or allergic reactions in which the amine invades the plasma compartment more slowly, but for a longer time period.

The neurogenic-inflammatory mechanism of histamine release includes also the stimulation of pain fibers (C-fibers), as in the neuroendocrine mechanism, but via axon reflexes. These fibers directly stimulate mast cells by the peripheral release of peptidergic neurotransmitters without the detour via the central nervous system $[19,25]$. Hargreaves and Dionne [33], have proposed a most exciting scheme for illustrating the relationship of several mediator systems (fig. 2) in which histamine is released by substance P. However, many more peptides are involved in such release 


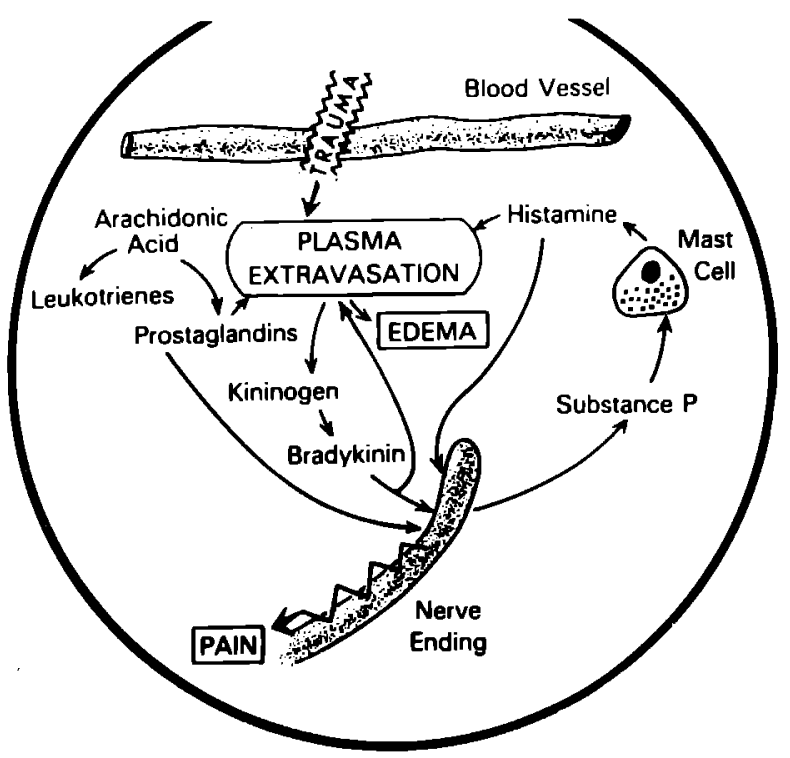

Fig. 2. - A model for evaluating endogenous mediators of pain and analgesia in clinical studies: the case of neuroinflammatory release of histamine. Trauma (upper part of the figure) activates a cascade resulting in the synthesis or release of prostaglandins, bradykinin, substance $P$ and histamine (as well as other mediators not shown). The interrelationships of these inflammatory mediators form a positive feed-back loop allowing inflammation to persist far beyond cessation of the acute injury. From Hargreaves and Dionne [33]

mechanisms such as neurokinin $A$ and $B$, neurotensin, somatostatin, dynorphin A, bradykinin, and in addition also vasointestinal polypeptide and calcitonin gene-related peptides $[9,87]$.

Histamine release due to trauma and surgery, however, includes still the direct effects on mast cells in the injured tissue which are destroyed by such a procedure. It is possible to denominate this type of histamine release as cytotoxic. Ischaemia is such a mechanism, but also the reperfusion injury after ischaemia including oxygen free radicals which have been studied intensively in the last few years $[5,20,49,50,80,97]$. Thermal injury includes coagulation of tissue for stopping haemorrhage which in conventional cholecystectomy [96] is involved in the "wound toilet " after removing the gallbladder. Mechanical injury is the dissection or disruption of tissue such as liver or mediastinal connective tissue in liver resection or oesophagectomy [99] where histamine release was shown immediately after the event by increases of the plasma histamine level.

Finally, however, a new mechanism of histamine release was really invented in the last few years : the cytokine-induced release which acts on a local basis creating a microenvironment [24] for the individual mast cell. This facilitates mediator release [10, 47]. KAPLAN et al. [40] defined histamine releasing factors as products of activated cells (cytokine-like molecules) that interact with basophils and/or mast cells to cause the release of histamine. Others defined cytokines themselves as histamine releasers or modulators of histamine release (IgE-mediated or sometimes also nonspecific release) : tumor necrosis factor $-\alpha[26,27$, $88,107]$, interleukin-3 [7, 28, 48, 81], interleukin-1 $[6,88]$, interleukin-5 [7, 35, 43], interleukin-8 [4], granulocyte macrophage colony stimulating factor (GM-CSF) [7], connective tissue-activating peptide III $[28,46]$. All these cytokines are produced (expressed) by macrophages, mast cells, endothelial cells and fibroblasts. These cells occur in many tissues, but also and in some species especially abundantly in the connective tissue of the peritoneum [11]. These cells respond to surgical injury [18].

\section{Pathogenesis}

In pathogenesis, as the second part of the causality chain in the epidemiological model of a disease, histamine does not only provide direct actions on a variety of cells (smooth muscle cells, endothelial cells, secretory cells) in the cardiovascular, respiratory and gastro-intestinal systems, but is also a marker for mast cell activation (fig. 1). Increased plasma histamine points to the release and formation of other mediators, such as tryptase, leukotrienes, complement factors and cytokines. In this connection it must, however, be emphasized that drug-induced pseudoallergic histamine release can be selective, i.e. it may not be accompanied by the concomitant release of prostaglandin $\mathrm{D}_{2}$ or leukotrienes [101].

\section{Disease manifestation}

In disease manifestation, as the third part of the causality chain (fig. 1), histamine does not only produce cardiovascular disturbances and respiratory reactions and/or complications (with some probability) in the postoperative period. Histamine and other mast cell products are - according to much recent research - also involved in metabolic reactions to trauma, in thrombosis, infections, fibrosis and postoperative adhesions and hence have to be completely revisited concerning their possible clinical relevance. Examples for these effects were already published in 1985 [68], but were augmented by recent reviews in anaesthesiology $[84,85]$. The most comprehensive table on such functions of mast cell mediators, however, was published by WershIL and Galli [110]. A modified, simplified table is constructed in this conceptual article on histamine release (table I).

The new classification of perioperative histamine release illustrates that measured plasma histamine increase can no longer be easily taken as an indicator of tissue histamine release by an exhausting and detrimental degranulation process. Increased plasma histamine may originate from tissue mast 
Table I. - Proposed roles of mast cells in biological responses relevant for anaesthesia and surgery.

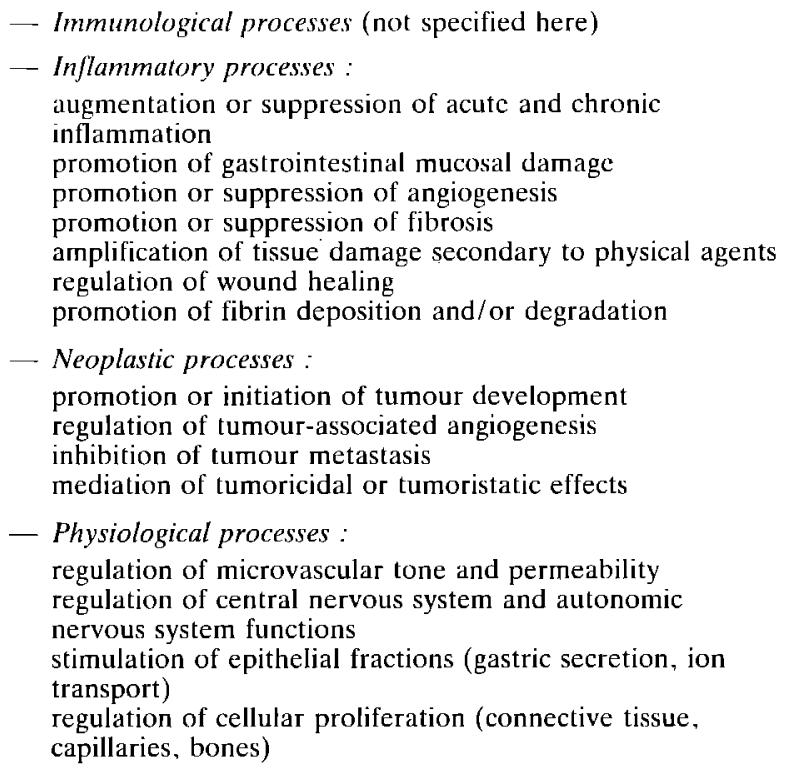

Modified from WershiL and Galli [110].

cells, basophils, endocrine cells (EC1 cells in the gastrointestinal tract) or peripheral and central nervous tissue. Increased plasma histamine may stand for its own or may be an indicator for a whole battery of mediators unwanted in a particular clinical situation. Increased plasma histamine may be unwanted and detrimental and therefore the objective for an antihistamine prophylaxis [68] or it may be beneficial [12] and therefore not at all a matter to be worried about. The new and more differentiated classification of perioperative histamine release makes a careful decision making mandatory which depends on the specific clinical situation (e.g. the particular drug which is given). There is no way for an oversimplification, like in the case of other types of preoperative prophylaxis such as that for stress ulcer, surgical infection and thrombosis.

Four recently conducted and completed prospective and randomized clinical trials will demonstrate this with somewhat astonishing data and findings.

\section{FOUR PROSPECTIVE CLINICAL TRIALS FOR CLASSIFICATION OF HISTAMINE RELEASE}

Short communications were already published for all the trials in this article $[14,98,102,103]$ as well as full papers on the definition and measurement of serial histamine release in these clinical conditions $[13,71,75,96]$. However, for a better understanding, details of the methods will be given in the following sections.

\section{Trial 1}

All 240 patients undergoing general surgery (age 18-83 years, 116 male, 124 female, without a case history of allergy, ASA 1-3) were selected from the total population (4 230 patients) of the Clinic of General Surgery in Mainz by a defined selection and randomization procedure [71] (1 patient/ day). The first patient was recruited in December 1988, the last patient in September 1991. Only 9 patients became drop-outs $(3.75 \%)$. Following final recruitment in the morning of the operation day the patients were allocated to one of four treatment policies (table II). The drugs (antihistamine prophylaxis and Haemaccel-35 therapy) were administered in a double-blind manner - a procedure which was proved to have been successful even with the plasma substitute. The technician measuring plasma histamine and the study leader analysing the data in a first evaluation after the end of the trial were also unaware of the treatment strategies (quadruple-blind design). The data were collected two weeks by the monitor and plausibility controls were performed continuously by one of the study leaders in each patient. After completing the trial performance, all cases were analysed first by one of the study leaders (W.L.) and the monitor in the same session. This analysis was controlled by the anaesthesiological coordinator of the study (D.D.) and critical cases were presented to the anaesthesiological study leader (W.D.). After this analysis a meeting of all members of the study team [71] with the advisory group was performed at February 13, 1992. At this meeting the random code was broken by a member of the advisory group (M. Rothmund) and the statistical analysis was then performed by the statistical coordinator who was not involved in the first part of the (descriptive) data analysis.

Table II. - Test and control groups for the controlled clinical trial with $\mathrm{H}_{1}-+\mathrm{H}_{2}$-prophylaxis and Haemaccel-35 therapy (MainzMarburg trial).

\begin{tabular}{|c|c|}
\hline Groups & Treatment policies \\
\hline Test group & $\begin{array}{l}\mathrm{H}_{1}+\mathrm{H}_{2} \text { prophylaxis and Haemaccel-35 } \\
\text { therapy }\end{array}$ \\
\hline Control group 1 & $\mathrm{NaCl}$ prophylaxis and Ringer therapy \\
\hline Control group 2 & $\mathrm{H}_{1}+\mathrm{H}_{2}$ prophylaxis and Ringer therapy \\
\hline Control group 3 & $\mathrm{NaCl}$ prophylaxis and Haemaccel-35 therapy \\
\hline
\end{tabular}

For understanding the difficult time relationships in this routine study in the preoperative period, treatments and investigations in the single patient are shown in figure 3. Following premedication 


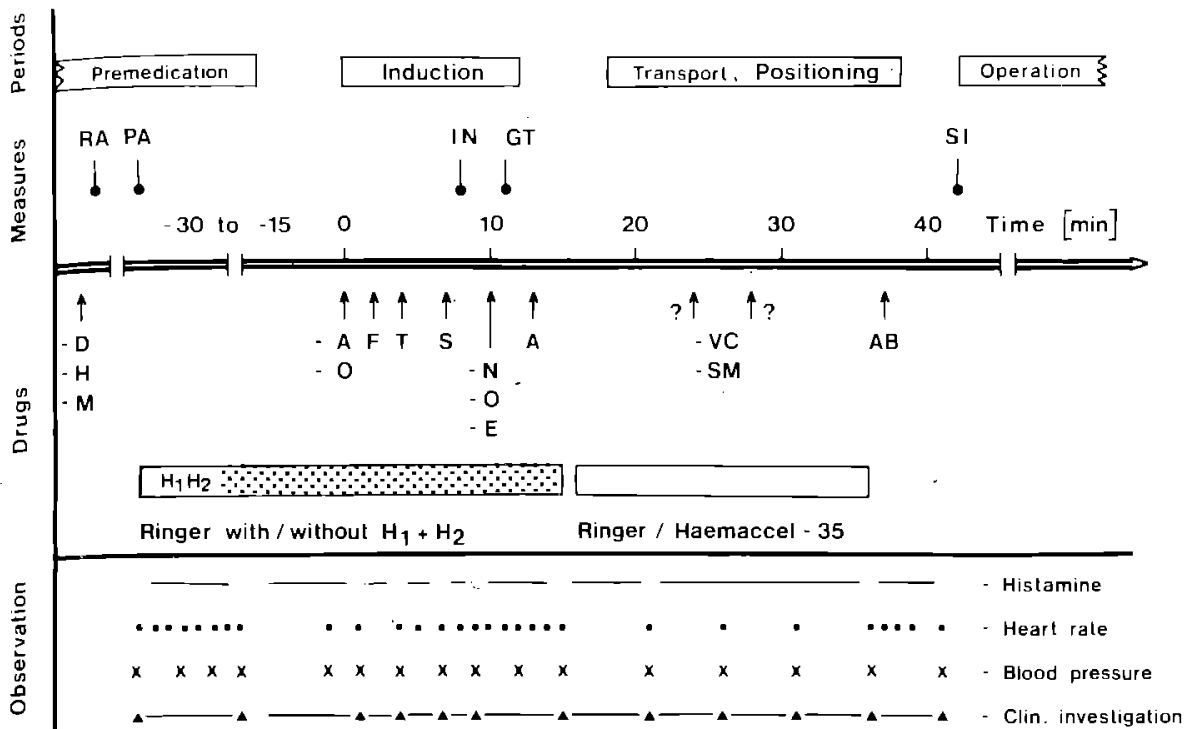

Fig. 3. - Schematic description of the treatments and investigations in a single patient of the Mainz-Marburg trial.

$\mathrm{D}=$ diazepam, $\mathrm{H}=$ heparin, $\mathrm{M}=$ miscellaneous, depcnding on medication for specific perioperative risk (hypertension, diabetes, etc.). RA$=$ randomization, $\mathrm{PA}=$ peripheral access, $\mathrm{A}=$ alcuronium, $\mathrm{O}=$ oxygen, $F=$ fentanyl, $T=$ thiopental, $\mathrm{S}=$ suxamethonium, $\mathrm{N}=$ nitrous oxide, $\mathrm{E}=$ enflurane, IN = intubation, $\mathrm{GT}=$ gastric tube, $\mathrm{VC}=$ vasoconstrictors, $\mathrm{SM}=$ stabilizing medications for haemodynamics, respiration and the electrolyte and acidbase systems. $\mathbf{A B}=$ antibiotics (metro-nidazole, ccfuroxine), $\mathrm{SI}=$ skin incision. $\mathrm{H}_{1} \mathrm{H}_{2}=$ dimethindene $(0.1 \mathrm{mg} / \mathrm{kg}$ i. v. $)+$ cimetidine ( $5 \mathrm{mg} / \mathrm{kg} i . v_{\text {. }}$ ) connected to the infusion of Ringer solution.

with flunitrazepam p.o. and insertion of two peripheral-venous accesses, the basic data were collected for heart rate (ECG), blood pressure (Dinamap ${ }^{(\circledR)}$ ) and plasma histamine. According to the exact time schedule (fig. 3) measurements and blood sampling were carried out after the antihistamine $\mathrm{H}_{1^{-}}+\mathrm{H}_{2}$-prophylaxis (dimethindene maleate, $0.1 \mathrm{mg} \cdot \mathrm{kg}^{-1}$, Zyma Company (Munich, Nyon) and cimetidine, $5 \mathrm{mg} \cdot \mathrm{kg}^{-1}$, Smith Kline Beecham (Munich) or placebo, after alcuronium, fentanyl and thiopentone for induction of anaesthesia, after suxamethonium and intubation, after maintenance of anaesthesia with $\mathrm{N}_{2} \mathrm{O} / \mathrm{O}_{2}$ and enflurane, after administration of a full relaxing dose of alcuronium and slow infusion $(20 \mathrm{~min})$ of a plasma substitute (Haemaccel-35 or Ringer, $500 \mathrm{ml} /$ patient) for haemodynamic stabilization. Finally, antibiotics were given (cefuroxime, metronidazole) in about half of the patients before start of operation (skin incision). All physical measures in the period of investigation such as insertion of the gastric tube, transport and positioning were also exactly (min per min) recorded. This will be important in analysing the exact time of application for all interventions of the active anaesthesist in the phase of stabilization of the patient (infusion of plasma substitute). It should be emphasized that the anaesthesist performing the anaesthesia and that observing the whole procedure were always different persons. The status of training and education in anaesthesiology was assessed for both the acting and the observing anaesthetists and was in agreement with good standards of treatment.

\section{Trial 2}

The cross-sectional study [102] was designed and conducted according to LoRENZ et al. [76] with features of well-designed observational studies (similar to randomized trials). They included complete protocol before start (including approval by ethical committee), elimination of Berkson bias (only hospitalized, surgical patients), defined entrance criteria for cases and controls, assignment to groups not predictable, balanced assignment (10 subjects in each group), prognostic factors (e.g. ASA classes) distributed uniformly, diagnostic information identical for both groups, assignment of patient's samples to histamine assay by randomization, quality control of the assay and drug interference monitoring. These rigid criteria were fulfilled by selecting 10 patients in a normal ward in the Department of General Surgery on day 5 after operation, without infection or other surgical complications, in the morning as in the case of the 10 patients in the control group who were prepared for operation in the parallely ongoing trial with histamine antagonists (Mainz-Marburg, trial 1). Blood samples were taken at exactly the same time in the resting patients on the ward as in the patients during induction of anaesthesia (fig. 3). The $2 \times 10$ patients in the study had an age between 18 and 80 years, included both sexes in equal proportions and showed a preoperative risk of ASA 1-3. This trial was repeated one year later in another $2 \times 10$ patients using the same design of the study.

\section{Trial 3}

The prospective study [103] was designed and conducted with the same rigid criteria as the crosssectional study in trial 2, with the exception of a control group and these parameters which refer to that. The 12 patients had an age of 58 [42-84] years (median and range), a sex of 8 males and 
4 females and again ASA classes 1-3. The endoscopy of the upper gastrointestinal tract was performed routinely, but the psychometric interview including a 2-step audiovisual ring scale for measurement of anxiety in a modification of the method of ANDREws [2], the ECG recording and the blood sampling was added to the usual procedure. In addition, the patients were prepared for the study in a separate room before announcement of the start of endoscopy, then they were transferred to the endoscopy unit. The defined time periods for measurement included $2 \mathrm{~min}$ after peripheral venous access, after $10 \mathrm{~min}$ waiting, after the announcement of endoscopy (acute anxiety), at the deepest point of endoscopy (duodenal C), after completing endoscopy and after a $30 \mathrm{~min}$ recovery period. Catecholamines were not determined after the peripheral venous access because for methodological reasons this value was always considered as "artificially" elevated [8]. The value $30 \mathrm{~min}$ after endoscopy served as a base-line plasma catecholamine level.

\section{Trial 4}

The prospective study was again designed and conducted with the same rigid criteria as the crosssectional study in trial 2 [98]. For instance, quality control was performed for each single patient and drug interference was carefully monitored for all histamine and catecholamine assays. Because of symptomatic cholelithiasis 11 patients underwent laparascopic cholecystectomy. Their age was 1956 years, 10 were female, only one was male, and they showed a perioperative risk of ASA classes 1-3. The protocol for anaesthesia was standardized and included vecuronium and methohexitone as drugs with a low potential of histamine release. The measurements and taking of blood samples for plasma histamine and catecholamine levels were carried out 10 and $5 \mathrm{~min}$ before starting operation (insertion of the Veress needle) (B1 and $\mathrm{B} 2$ as basal values 1 and 2 ), every min after insertion of the first trocar and the second trocar for $5 \mathrm{~min}$ as a specific phase in laparascopic cholecystectomy. As a phase of operation which is similar in conventional cholecystectomy as in laparascopic cholecystectomy, the dissection of the gallbladder from the liver bed was chosen. This period was simply and intuitively divided into 5 periods corresponding to the start of dissection. after $1 / 3$, after $2 / 3$ and after complete dissection of the gallbladder from the liver bed and exactly 5 min after the removal of the organ from the liver bed.

\section{Methods applied in all four trials}

Measurements and statistics

They were described in detail in the protocol of the Mainz-Marburg trial [71], but also in the origi- nal paper about the second trial [75] and shortly in the short communications [98, 102, 103]. It is important to emphasize that all the four trials used the same rigid criteria for the fluorometricfluoroenzymatic plasma histamine assay as described by LoRENz et al. [58] and modified by Lorenz and Neugebauer [73] and demanded in the Consensus Conference on Histamine Assays [74]. Plasma catecholamines were determined by a HPLC-technique [21]. Heart rate and blood pressure were assessed by physical methods which are standard today (ECG monitoring, Dinamap ${ }^{\circledR}$ ). The statistical analysis with methods given in results was performed by using SAS statistical software.

Definition of histamine release

and of a systemic histamine release reaction

The criteria which had to be fulfilled were described in detail by LORENz et al. [64, 66, 68], Duda et al. [13] and SitTer et al. [99].

However, histamine release as measured by an increase of plasma histamine, and histamine release reactions are different variables. Histamine release is a biochemical parameter, histamine release reaction is a clinical reaction which is diagnosed by the clinician using a set of signs and measurements [75]. According to LoReNz et al. [66] histamine release reactions show 3 grades of severity : cataneous, systemic and life-threatening. Only systemic (grade II) and life-threatening (grade III) reactions were considered in this communication.

\section{RESULTS OF THE FOUR CLINICAL TRIALS FOR CLASSIFYING HISTAMINE RELEASE BY AETIOLOGICAL MECHANISMS}

Trial 1 : Drug-induced pseudoallergic histamine release

The Mainz-Marburg trial on histamine release and cardiovascular and respiratory disturbances in the preoperative period served as an excellent possibility for classifying different types of histamine release. Some of the conditions for that were planned : polygeline (Haemaccel ${ }^{\circledR}$ ) chosen as a nonspecific histamine releaser inducing pseudoallergic reactions [65], was applied deliberately in the post-induction phase of anaesthesia with its clinically demanded steady state and was administered to patients who received either placebo or $\mathrm{H}_{1}-+\mathrm{H}_{2}$-antihistamines introducing specificity and causality into the classification.

However, the high incidence of histamine release in every phase of the preoperative period (table III) was not planned at all : the investigators were shocked, but continued the trial in agreement with the advisory group because what the trial investigated was simply clinical routine. 
Table III. - Incidence of histamine release during preoperative anaesthesia and preparation of the patient for surgery.

\begin{tabular}{lcc}
\hline \multirow{2}{*}{ Drugs and measures } & \multicolumn{2}{c}{ Incidence } \\
\cline { 2 - 3 } & $(\mathrm{n})$ & $(\%)$ \\
\hline Antihistamines & 39 & 16 \\
Alcuronium (low dose) & 32 & 13 \\
Fentanyl & 39 & 16 \\
Thiopentone & 32 & 13 \\
Succinylcholine-intubation-enflurane & 36 & 15 \\
Alcuronium (high dose) & 37 & 15 \\
Plasma substitute & 71 & 30 \\
Antibiotics & 31 & 13 \\
\hline Total preoperative preparation & 173 & 72
\end{tabular}

$\mathbf{n}=240$ patients, drop-out cases were not treated separately. In the phase of antihistaminc prophylaxis half of the paticnts received placebo $(\mathrm{NaCl})$, half of them $\mathbf{H}_{1}-+\mathrm{H}_{2}$-antagonists. In the phase of plasma substitutes again half f the patients reccived Ringer as a "placebo solution and half of them ref the phase of antibiotics about half of the patients received he drug, half of them did not depending on the type of operation, but not on randomization. All other drugs were given to all patients in study. From DudA et al. [14].

People may point to Haemaccel ${ }^{\circledR}$. The findings, however, with the other drugs used relativate such a conclusion drawn at a first glance. On the contrary, Haemaccel ${ }^{\circledR}$ proved very suitable for not only classifying drug-induced pseudoallergic histamine release, but also for finding the clinical signs of such reactions in the perioperative period which are different from those in a conscious subject taking only a single drug. In addition, the clinical relevance of histamine release could be demonstrated at least for that phase. Hence Haemaccel $\left.{ }^{(}\right)$was a scientific stroke of luck. It changed current paradigms on histamine release in clinical anaesthesia. This will be demonstrated by case reports (fig. 4 and 5) which are more illustrative for the clinicians than the nude numbers in a contingency table.

First of all, systemic histamine release reactions occurred not only in the Haemaccel group, but also in the Ringer group and with an incidence $(8,5 \%)$ which by no means was negligible. It was reduced by the antihistamine prophylaxis to an extend of $75 \%$. In the Haemaccel-35 group systemic and life-threatening histamine release reactions (severity grade II and III) occurred in $32 \%$ of the patients - an incredibly high incidence. They were reduced to an incidence of $14 \%$ in the group with antihistamine premedication which was statistically significant ( $\mathrm{p}<0.03$ ) (chi 2 test).

There was one case of intraoperative death in the whole trial. The patient with oesophageal cancer ( $\mathrm{N}^{\circ}$ 220/ASA 2) developed ventricular fibrillation after considerable blood loss which was judged as the cause of the severe reaction - until plasma histamine data were available : histamine levels of $12 \mathrm{ng} \cdot \mathrm{ml}^{-1}$, were associated with hypotension which was successfully treated, but not with any cutaneous signs. Histamine is highly arrhythmogenic [55], and the severe incident did not happen in any other group of the trial, but in the placebo-Haemaccel group where most of the other reactions also occurred. A confounding effect of histamine release and blood loss could
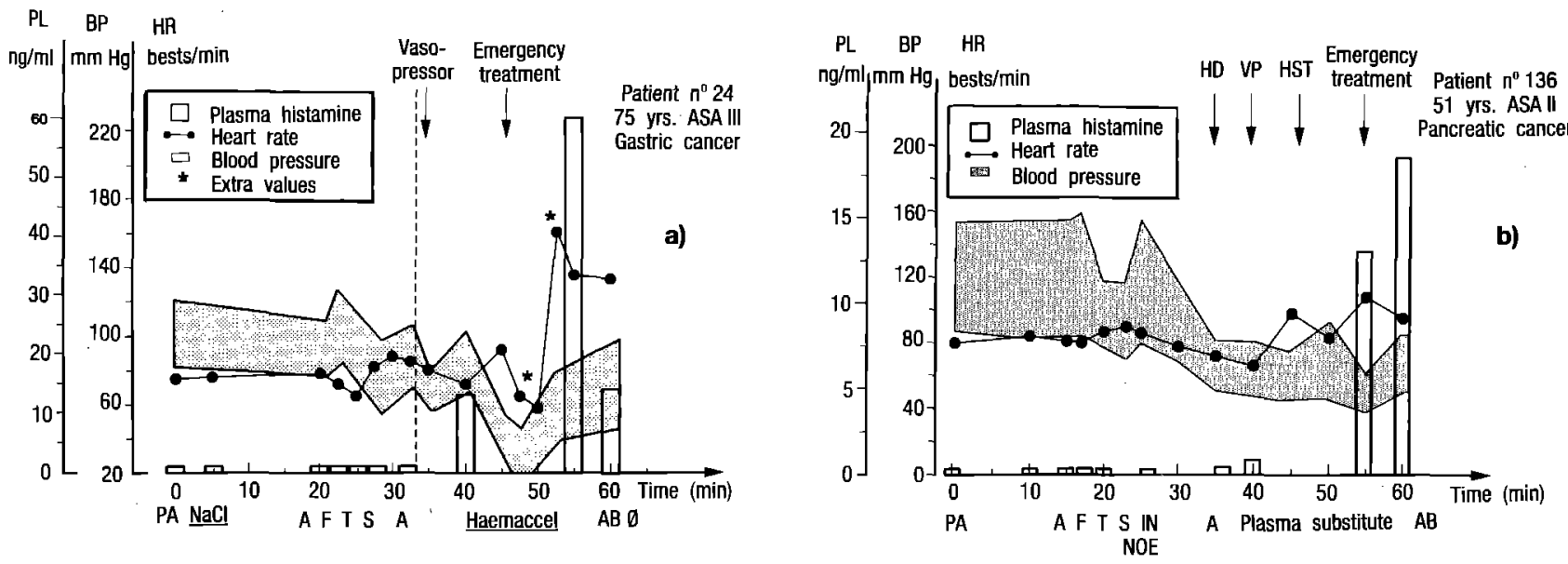

Fig. 4 (a, b). - The two patients with life-threatening histamine release reactions in the Mainz-Marburg trial.

The data of the first patient are shown in figure $\mathbf{4 a}$, those of the second one in figure $\mathbf{4 b}$. Both patients were suffering from abdominal cancer. The external study advisory group reported after completing the trial by September 1991 that both patients received placebo as the premedication. The code for the blinded doctors and evaluators of the study was not opened at this time. PL $=$ plasma histamine level, $\mathrm{BP}=$ blood pressure, $\mathrm{HR}=$ heart rate, $\mathrm{HD}=$ head-down position, $\mathrm{VP}=\mathrm{vasopressor}\left(\mathrm{Akrinor}{ }^{\circledR}\right.$ which includes 7-[2-(2-hydroxy-1 methyl-2-phenylethyl-amino) ethyl] theophylline and theodrenaline), HST = hetastarch. Emergency treatment included delivery of pure oxygen, Ringer solution as plasma substitute, epinephrine, corticosteroid and the $\mathrm{H}_{1^{-}}+\mathrm{H}_{2}-\mathrm{receptor}$ antagonists involved in the study. PA, etc. are explained in fig. 3. 
not be excluded as the cause of ventricular fibrillation and is the most likely explanation.

The two other reactions of high severity (grade III = life-threatening) are self-explanatory (fig. 4a, b). Since these two occurred both in the placebo group, their incidence was not in the range $1: 1000$ or $1: 10,000$, but as high as 2 : 116 or $2 \%$. These two cases were described in detail elsewhere [13], and for this reason only a few details are mentioned :

- Patient $\mathrm{N}^{\mathrm{O}} 24$ with gastric cancer, ASA 3, showed $10 \mathrm{~min}$ after start of the Haemaccel ${ }^{(B)}$ infusion a severe decrease of blood pressure down to $40 \mathrm{mmHg}$, i.e. shock values. This hypotension occurred in combination with bradycardia (not tachycardia) and made emergency treatment mandatory. The plasma histamine levels were consistent with those of a life-threatening reaction [77].
- Patient $\mathrm{N}^{\circ} 136$, a 51 years old woman with pancreatic cancer, ASA 2, developed a similar severe reaction. The further increase of plasma histamine after administration of the antibiotics and emergency treatment is here of special interest. Since, however, emergency treatment in combination with $\mathrm{H}_{1}+\mathrm{H}_{2}$ blockers as treatment preceeded this further increase it may have shown no further haemodynamic consequences.

In another class of clinical judgement fell those systemic histamine release reactions which comprised 12 patients $(20 \%)$ in which the anaesthetist acted with measures for stabilizing haemodynamics. Retrospectively most of these reactions were kept in mind as " uneventful " meaning " business as usual " because anaesthetists expect some cardiovascular instability after induction of anaesthesia. However, they cannot think about the
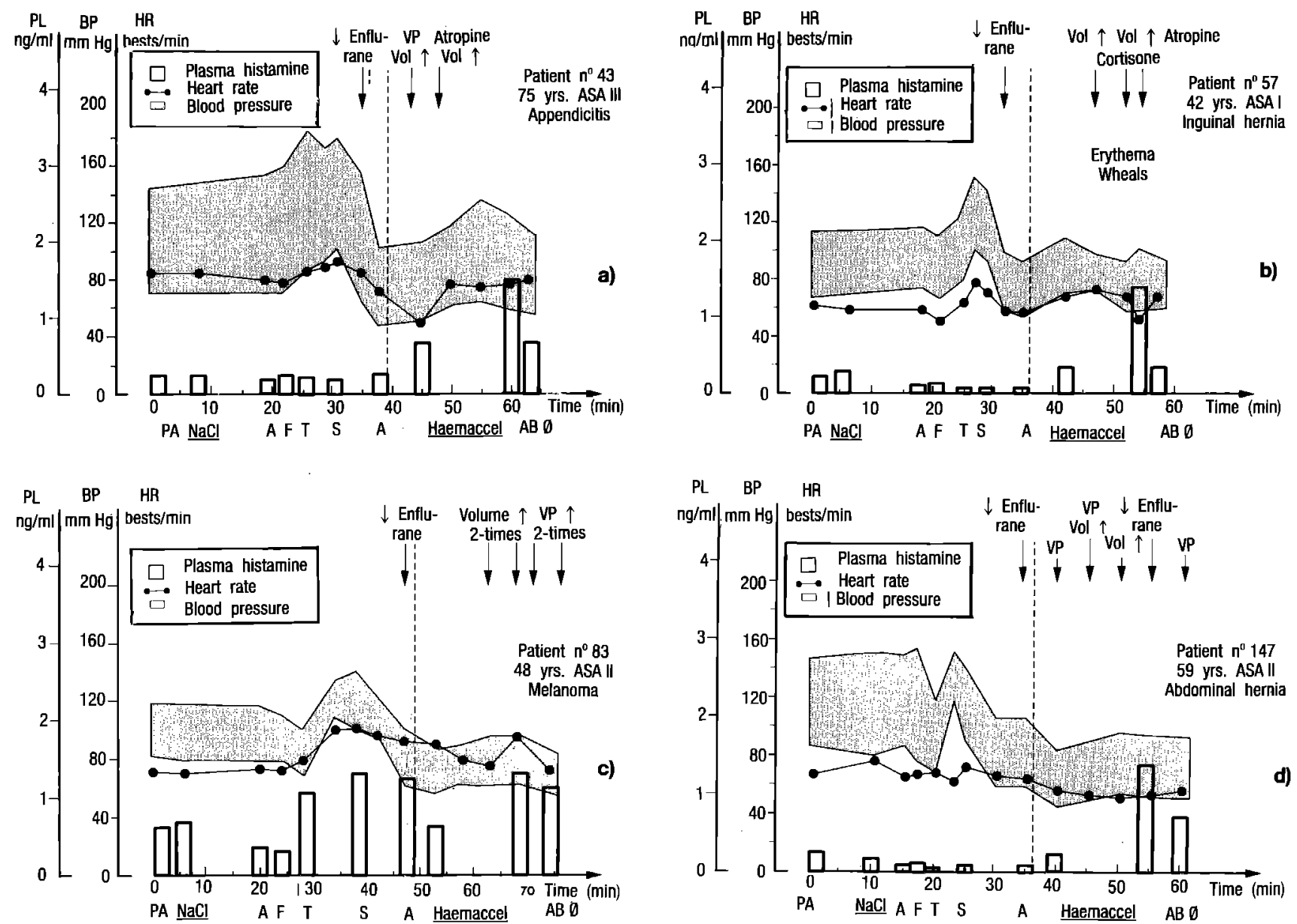

Fig. 5 (a, b, c, d). - Four patients with systemic histamine release reactions selected at random from 12 " uneventful " cases in the Mainz-Marburg trial in which later on histamine release was demonstrated by measuring plasma histamine. PL $=$ plasma histamine level, $\mathrm{BP}=$ blood pressure, $\mathrm{HR}=$ heart rate. $\mathrm{AB} \varnothing=$ no antibiotics given, for other abbreviations in this line see fig. 3 . Single patients : 5a : $N^{\circ} 43$ : VP = vasopressor (always Akrinor ${ }^{(1)}$ ) ; Vol = volume substitution either by additional Ringer or by accelerated

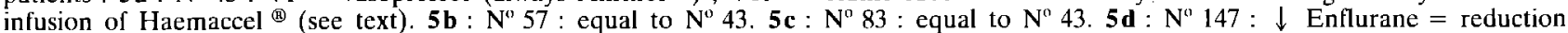
of the pressure of the volatile gas. 
cause of these reactions if no cutaneous or bronchospastic clinical signs are recognized. What, however, is most remarkable in these reactions is the small increase in plasma histamine levels at which they occur - apparently at a time when the patient is more susceptible, more triggered [37] to the effects of histamine by the load of drugs which he has already received. The causal role of histamine in these reactions of cardiovascular instability is best demonstrated by the finding that also 5 reactions occuring after Ringer solution included intervention of the anaesthetist whereas all reactions in the $\mathrm{H}_{1}+\mathrm{H}_{2}$ group including Haemaccel ${ }^{(B)}$ were not associated with a severity which was judged by the anaesthetist as needing an intervention. In the Haemaccel group with placebo premedication this occurred only in 3 patients as the lowest class of clinical judgement ( not relevant for an intervention $"$ ).

To illustrate this new dimension of the clinical problem with histamine release 4 of the 12 cases will be presented in detail (fig. 5a-d).

- Patient $\mathrm{N}^{\circ}$ 43, ASA 3 (fig. 5a) was hypertensive with blood pressure values up to $180 \mathrm{mmHg}$ systolic until endotracheal intubation was completed. Thereafter enflurane gas concentration was reduced before injection of the full relaxation dose of alcuronium. Five minutes after start of the infusion of Haemaccel-35, intervention with a vasopressor (Akrinor ${ }^{\circledR}$, theophylline derivative in combination with theodrenaline) and fast infusion of additional Ringer's solution was necessary to maintain a blood pressure level of $106 \mathrm{mmHg}$ systolic. The histamine plasma level at this time had increased from $0.26 \mathrm{ng} \cdot \mathrm{ml}^{-1}$ to $0.67 \mathrm{ng} \cdot \mathrm{ml}^{-1}$. Bradycardia down to $50 \mathrm{~b} \cdot \min ^{-1}$ was treated by atropine $0.5 \mathrm{mg}$ i.v., fast infusion of Ringer's was continued. Although the plasma histamine level had increased up to $1.49 \mathrm{ng} \cdot \mathrm{ml}^{-1}$ until the end of the Haemaccel-35 phase, this treatment was effective enough to increase the heart rate to at least $77 \mathrm{~b} \cdot \mathrm{min}^{-1}$ and to bring the blood pressure up to $126 \mathrm{mmHg}$ systolic - but only for a short time.

- In patient $\mathrm{N}^{\circ} 57$, ASA 1 (fig. 5b), no dramatically severe haemodynamic reactions occurred. However, in the Haemaccel ${ }^{\circledR}$ phase the anaesthetist intervened four times to counterbalance long lasting hypotensive «tendencies »- by reduction of anaesthetic gas concentration, by rapid volume infusion and even injection of a corticoid after the appearance of cutaneous signs. Finally, following cortisol injection - a further increase of plasma histamine which was accompanied by bradycardia was treated with atropine.

- Patient $\mathrm{N}^{\circ} 83$, ASA 2 (fig. 5c), had a basically elevated histamine level which further increased during intubation and plasma substitute infusion. Systolic blood pressure was around $90 \mathrm{mmHg}, 5 \mathrm{~min}$ after start of Haemaccel-35 infusion and enflurane concentration was reduced.
Infusion speed of the plasma substitute was increased two times and two injections of a vasopressor (Akrinor ${ }^{\circledR}$ ) were regarded as necessary to rise the blood pressure, but without success. Treatment without success can be regarded as a clinical sign of the effects of histamine release in that situation.

- Patient $N^{0}$ 147, ASA 2 (fig. 5d), showed even more such a haemodynamic reaction with many interventions of the practising anaesthetist. Reduction of gas concentration, injection of vasopressor and therapy with volume was tried to counterbalance the low systolic blood pressures between 84 and $95 \mathrm{mmHg}$. There was almost no success. Plasma histamine levels rose to $1.38 \mathrm{ng} \cdot \mathrm{ml}^{-1}$ only - not a dramatic increase for so many interventions. This was not observed in the group with $\mathrm{H}_{1}+\mathrm{H}_{2}$ receptor antagonists.

Some characteristics of histamine release in the plasma substitute phase of the preoperative period were combined to explain why this clinically relevant histamine release was classified as druginduced pseudoallergic histamine release.

- First of all, 7 of 18 systemic histamine release reactions including those with grade III (life-threatening) were associated with plasma histamine levels below $1 \mathrm{ng} \cdot \mathrm{ml}^{-1}(40 \%)$. This justifies strongly the new definition of histamine release reactions. In addition, histamine release reactions were associated with bradycardia in the full setting of induction and maintenance of anaesthesia. This is different from the conscious human subject [66].

- Cutaneous reactions occur frequently in the conscious volunteers, but are more rare after induction of anaesthesia (only in $28 \%$ of the cardiovascular reactions associated with histamine release). This explains underreporting and many discussions about the clinical relevance of histamine release (wheals are not relevant, but cardiovascular disturbances cannot be ignored)!

- In many cases $(60 \%)$ the late time of response and the pharmacokinetics of histamine release are in favour of a pharmacological, not an immunological response. The large amount of protein should produce allergic reactions with proteinconjugate complexes almost immediately, but the observed responses occur quickly with Haemaccel ${ }^{\circledR}$ if applied within 3 min [66], but late if applied within $20 \mathrm{~min}$. These findings in the lifethreatening cases clearly support a considerable importance not only of allergic, but also of pseudoallergic reactions [17].

- A combination of drugs as triggers for the Haemaccel ${ }^{\circledR}$ and even for the Ringer response cannot be ruled out. Examples were given for nalbuphine versus fentanyl [12]. Carry-over effects of histamine release by alcuronium, however, did not play an important role. 
- Finally, from all clinical judgements in this phase of the preoperative management of the patient it is obvious that drug-induced pseudoallergic histamine release is an unwanted reaction (adverse reaction). That this is emphasized seems rather surprising, but this clear judgement does not hold true for the other following types of histamine release.

Trial 2: Neuro-endocrine induced histamine release. A temptative interpretation

The cross-sectional trial on serial histamine release in the preoperative preparation of the surgical patient versus changes in plasma histamine levels at the same time in patients of a normal ward.was conducted to test a hypothesis rising from the high incidence of histamine release in the Mainz-Marburg trial. It was questioned whether this high incidence was due to specific events in the preoperative period, not due to even minor stressors in daily life like insertion of a catheter, a hand grip, unpleasant talks, cough or pain during blood collection [108]. In addition to such factors of influence it was asked whether failures in blood sample taking and plasma preparation unavoidable in single cases would be able to produce spikes of increases in plasma histamine pretending histamine release even if trained and experienced technicians carried out this procedure.

The answers to these two questions were clearly «no" (fig. 6a, b) : because the questions were very important for interpreting the data of the Mainz-Marburg trial the cross-sectional study was later on carried out a second time and produced the same answers.

However surprisingly, the plasma histamine levels remained not constant, but showed a steadily decrease over time from $0.25(0.12-0.39) \mathrm{ng}$. $\mathrm{ml}^{-1}$ (median-range) to $0.09 \quad(0.03-0.26)$ $\mathrm{ng} \cdot \mathrm{ml}^{-1}$ after one hour. The persistent decrease was observed not only in the group of patients, but also in each individual subject. A series of findings let us suggest that the higher plasma histamine levels at the beginning than those later on were elicited by stress (venepuncture, anxiety, pain. awareness of a clinical situation with not completely certain consequences). First of all, such plasma histamine levels decreased after anaesthesia in man and animals [61] like those of plasma catecholamines $[91,92]$ " in the course of the neuroendocrine stress response ». They decreased steadily with time again like those of plasma catecholamines $[89,92,108]$, and a mutual influence of both types of biogenic amines on their release is also well known from the literature [70]. In addition, histamine release in association with pain in a dentist's chair was demonstrated [90]. Combining these findings with the data from the literature in the first part of this article (especially KNIGGE and WARBERG [45]) made such an interpre-
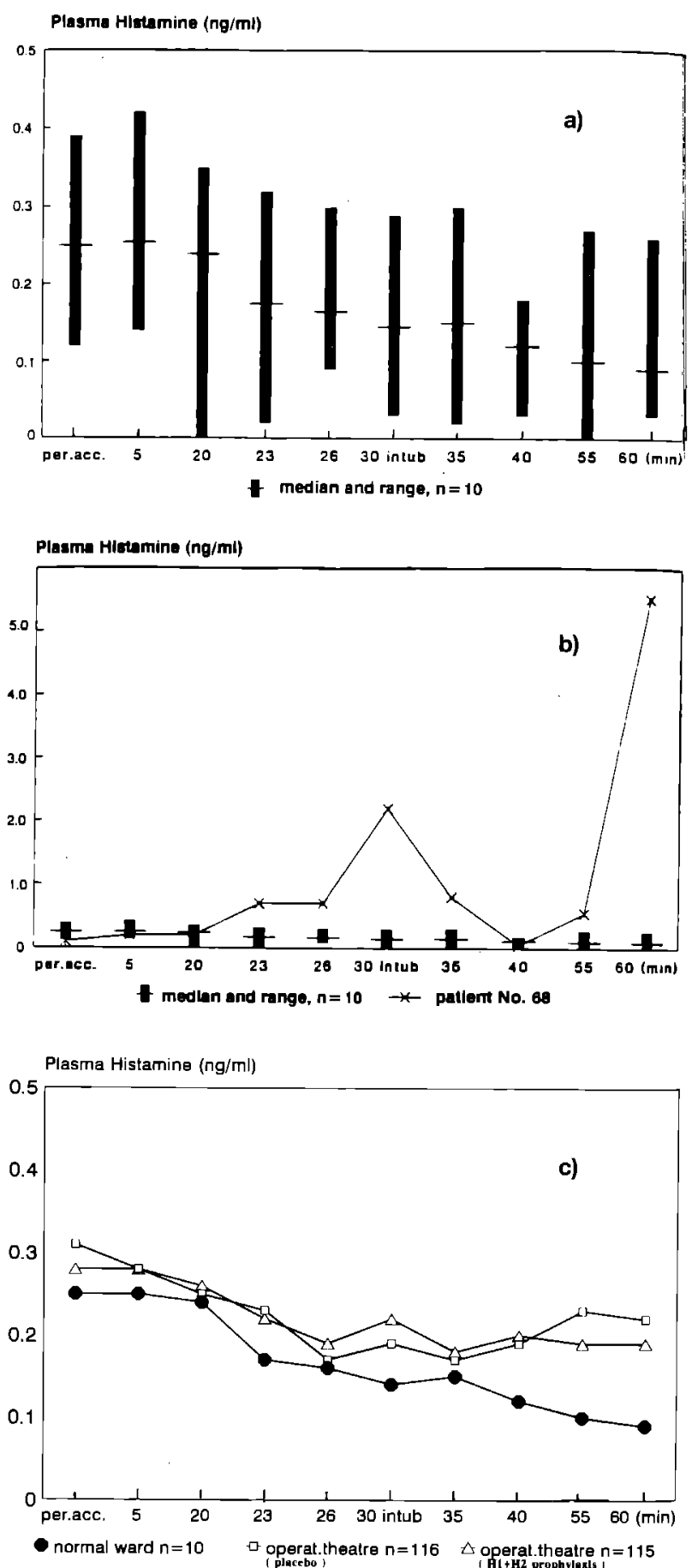

Fig. 6 ( $a, b, c)$. - Median plasma histamine levels in the time period of the preparation of the surgical patient in the MainzMarburg trial and in a prospective cross-sectional trial comparing patients in a normal ward with those in the operation theatre.

рег. acc. $=$ peripheral access (venepuncture) ; intub. = intuba tion. For further information see LORENZ ef al. [75] 6a patients in the normal ward (in supine position). $6 \mathbf{b}$ : one patient of the 10 in the cross-sectional study undergoing real anaesthesia. 6c : all patients within the Mainz-Marburg trial. Two groups comprise those with antihistamine or placebo prophylaxis. 
tation of the higher plasma histamine levels at the beginning of procedure likely which attempted to imitate the preparation of the surgical patient.

If this was true then it should be expected that on the average (median) such a decrease in plasma histamine levels should also be expected in the patients of the Mainz-Marburg trial. This was, indeed, the case (fig. 6c) - but only until the end of the induction of anaesthesia since in the plasma substitute phase thereafter histamine release was much more common. This may have increased the median.

This basic, longlasting (in contrast to the druginduced release with a half life of only few mins) and as neuroendocrine classified histamine release elicits several questions which cannot yet be answered: where does this histamine release come from? From tissue mast cells, mast cells in the vessel walls, basophils, neuronal or brain tissue? Is its mechanism not degranulation, but continuous intracellular histamine release [106] ? Does it occur after other stressful situations like intubation where catecholamines also rise $[32,95]$; and is the case shown in fig. $6 \mathrm{~b}$ already an example for that? Which factors define the pharmacokinetics of this histamine release if compared with histamine injection, infusion or drug-induced pseudoallergic histamine release from tissues [62, 66] ? Finally, is this neuro-endocrine histamine release unwanted (adverse), negligible or beneficial $[12,79]$ ? No answer can be given yet.

Trial 3: Neuro-endocrine induced histamine release. A more definite model

In the definition of stress by Monse et al. [82] this complex life and clinical scenario includes 3 components : stressors, individual make-up and the stress response. All three components guarantee a high variability in measured physical and biochemical parameters which also for stressinduced histamine release predicts non-responders, responders and superresponders as in the case of drug-induced pseudoallergic histamine release [63, $66,75]$. Upper gastrointestinal endoscopy with modern (small diameter) equipment, but without premedication in patients undergoing routine endoscopy (age about 50, with concomitant diseases) comprises many factors of stress in all three subgroups [82] : 1) physical and several psychological stressors, especially anxiety ; 2) make-up factors including age, personality (type As vs type Bs), traits and attitudes, emotional instability, etc. ; and 3) factors altering the stress response such as the degree of perceived control, current mood and stress perception.

For this reason, endoscopy as a stressful situation was chosen as a model in which the stressinduced histamine release was systematically investigated. The psychometric test with its two scales

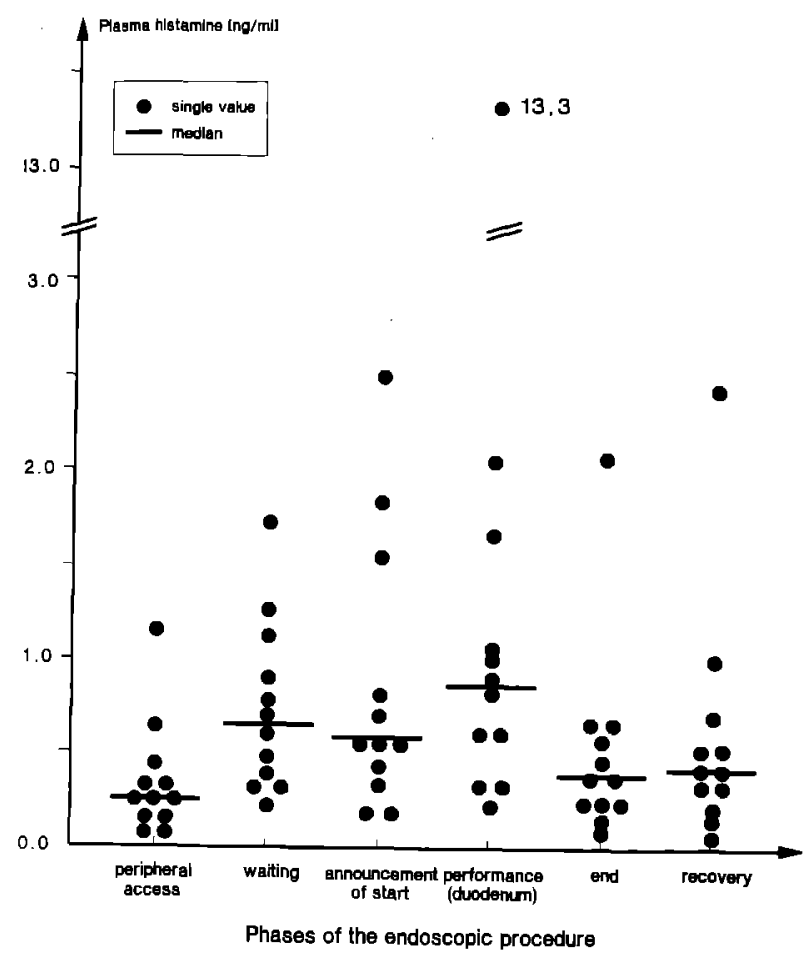

Fig. 7. - Histamine release before and during upper gastrointestinal endoscopy without premedication in patients of the routine programme of a surgical clinic. Single values and medians. Note the great variations in plasma histamine levels. In one superresponder endoscopy elicited plasma histamine levels up to $13 \mathrm{ng} \cdot \mathrm{ml}^{-1}$ which were usually only found in severe anaphylaxis. For further explanations see text

differentiated between anxiety and depressed mood. Plasma catecholamines were chosen as quickly increasing and decreasing biochemical variables and were compared with plasma histamine levels. Finally heart rate was chosen as a more sensitive parameter than blood pressure for changes in haemodynamics and was used as a physical variable of the stress response.

Indeed, histamine release occurred during endoscopy with an increase of plasma histamine within the expected great variation (fig. 7). However, none of us would even have expected that in one case plasma histamine levels were obtained which corresponded with $13.3 \mathrm{ng} \cdot \mathrm{ml}^{-1}$ to those in life-threatening allergic and pseudoallergic reactions (grade III). Histamine rose also on the average, but much less pronounced (fig. 8a) than in the one exceptional case (fig. 8b). In contrast to the patients in the normal ward (trial II), resting and supine position did not lower the plasma histamine levels, but raised them indicating histamine release - in agreement with anxiety and in contrast to the catecholamine levels which were fairly normal and corresponded also to those $30 \mathrm{~min}$ after ending endoscopy (recovery) - a time which was deliberately chosen from all 

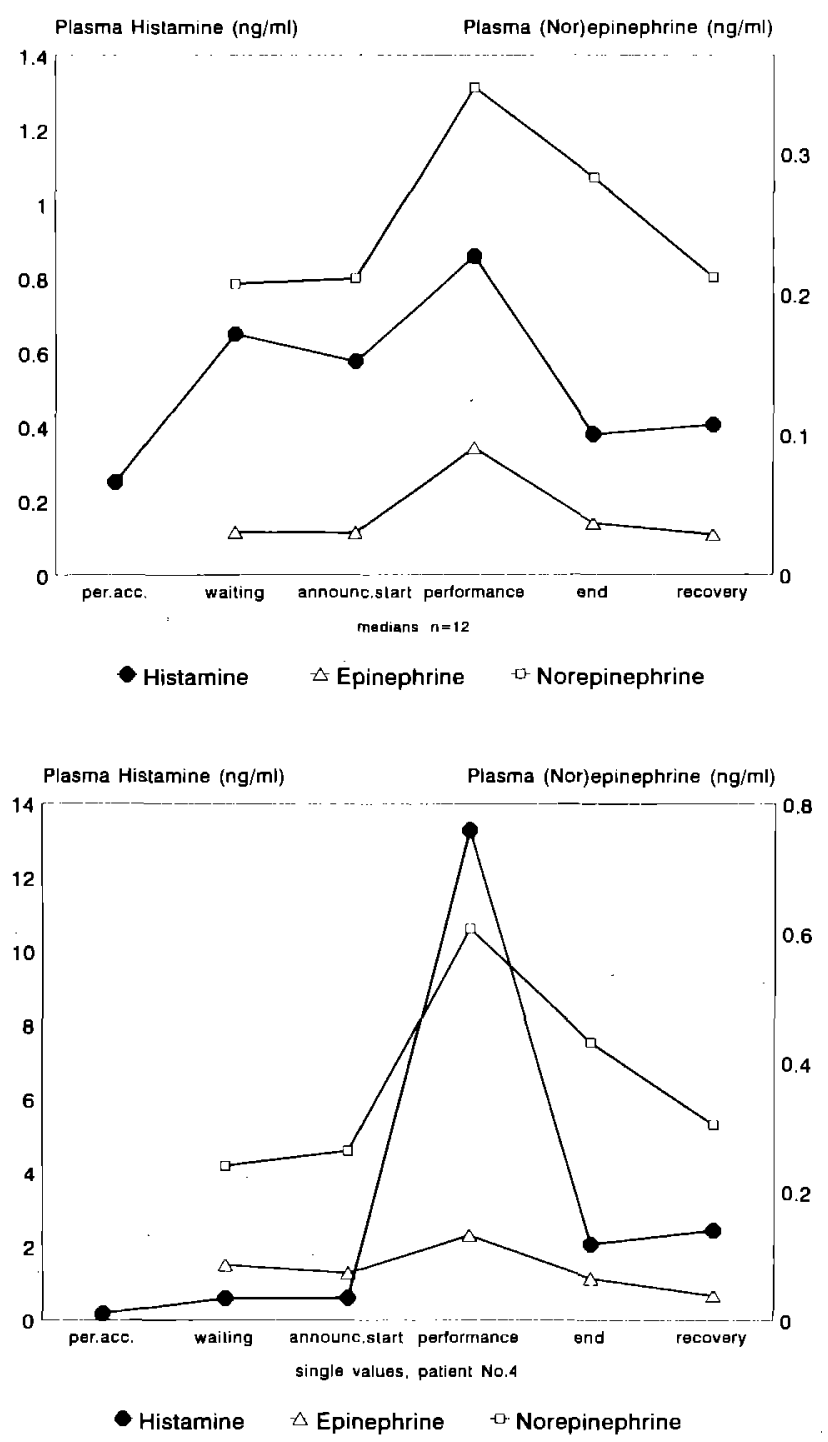

Fig. 8 (a, b). - Histamine and catecholamine release before and during upper gastrointestinal endoscopy without premedication in patients of the routine programme of a surgical clinic. Fig. 8a : median values of norepinephrine, epinephrine and histamine of $\mathbf{n}=12$. Fig. $\mathbf{8 b}$ : the superresponder case with highest plasma histamine levels.

catecholamine studies [108]. During performance of endoscopy histamine and the catecholamines increased in plasma both on the average (fig. 8a) and in individual cases (fig. 8b). The heart rate also increased on the average, but not considerably $\left(61,37,92,63,79,77 \mathrm{~b} \cdot \mathrm{min}^{-1}\right)$. In the exceptional case the highest increase in heart rate $\left(40 \mathrm{~b} \cdot \mathrm{min}^{-1}\right)$ of all patients was observed, but neither clinical signs of shock nor respiratory and cutaneous signs of an allergic or pseudoallergic reaction.

The considerable increase in plasma histamine (basal $0.18 \mathrm{ng} \cdot \mathrm{ml}^{-1}$, during endoscopy $\left.13.3 \mathrm{ng} \cdot \mathrm{ml}^{-1}=7400 \%\right)$ is not reflected in a similar increase in plasma catecholamines. Their increase corresponds to "modest stress », comparable to that observed on the average after venepuncture [108] or in the anaesthesized patient during coronary by-pass surgery $[36,100]$. In addition, the rise in histamine on the average occurs earlier than that in the catecholamines if the values in the recovery period are taken as controls (fig. 8a, b). Hence it is concluded that stressinduced (neuro-endocrine induced) histamine release exists in human subjects in clinical conditions and that it has to be distinguished from drug-induced pseudoallergic reactions in anaesthesia and surgery.

Mainly two questions arise from these findings which can temptatively be answered :

1) Where is so much histamine released to increase the plasma histamine levels up to concentrations found in anaphylactic shock? If it is neuroendocrine in origin, does it originate from the brain? Histamine is released into cerebrospinal fluid $[43,44]$ where it shows an approximately 30 -fold higher concentration than in plasma. In addition, it is rapidly metabolized [30], but anaesthesia and especially muscle relaxants may interfere with that $[22,34,57]$. Histamine as a neurotransmitter has found its role in neuroendocrine reactions (stress reactions) [29, 38, 39, 45] especially in endogenous non-opiate analgesia and is therefore centrally related to pain $[38,100]$, conditions which occur during endoscopy as well as fundamentally in surgery. Histamine release in the central nervous system is supposed to come from mast cells, from vascular smooth muscle, from unidentified cells which are neither neurons nor mast cells, from pineal body being influenced by sympathetic activity, or from nervous tissue in the midbrain [29].

2) If histamine rises in plasma up to such levels in the neuroendocrine response why does it not produce an anaphylactoid shock as in severe allergic and pseudoallergic reactions? An easy answer to that may be the functional antagonism of the catecholamines, but it is not as likely as another explanation: even a small dose of exogenous histamine $\left(0.45 \mathrm{ng} \cdot \mathrm{kg}^{-1}\right)$ injected intravenously as a bolus - to imitate the sudden increase of plasma histamine after intravascular release from basophils [66], produced plasma histamine levels in a human volunteer which rose as high as $20 \mathrm{ng} \cdot \mathrm{ml}^{-1}$ whereas the median increase of the group of volunteers was only $0.9 \mathrm{ng} \cdot \mathrm{ml}^{-1}$ after the same dose. Fortunately, these volunteers received the dose of histamine 4-times during a day, and hence this phenomenon could be reproduced in this particular volunteer. He showed a strong tachycardia to histamine, but only a minor decrease of blood pressure $(10 \mathrm{mmHg}$ !) and resembled clinically the one patient during endoscopy. 
From such findings we speculate that neuroendocrine induced histamine release originates from other sources than pseudoallergic histamine release. The first originates from cells or tissues which are relatively low in histamine content, but from which histamine enters the plasma directly like a histamine bolus injection (e.g. from basophils). The second originates from histaminerich tissues from which it is released from connective tissue mast cells and enters the plasma compartment more slowly and in a smaller proportion of the totally released histamine than in the case of a histamine bolus injection. Hence the clinical signs of histamine release in this aetiological type of release are more due to the large amount of free histamine in the tissue and in the neighbourhood of effector cells (smooth muscle cells, etc.) than due to the rise in plasma histamine.

The neuro-endocrine induced histamine release seems to produce clinical effects such as tachycardia which are, however, at present indistinguishable from the effects of catecholamine release. Because of that confounding effects no decision can be made whether it is unwanted or beneficial, but it seems unlikely that it is negligible.

Trial 4 : Laparoscopic cholecystectomy:

a complex scenario of intraoperative histamine release

It is most likely that cholecystectomy for reasons which were explained in the first (classification) chapter of this article combines several types of histamine release : 1) The neuro-endocrine and neuro-inflammatory induced types in the trocar phase with pain via the substance $P$ pathway and pain via the central nervous system; 2) the cytotoxic and cytokine-induced types in the phase of gallbladder dissection from the liver bed. The data which were obtained supported this hypothesis.

The placement of the first and second trocar through the abdominal wall (fig. 9) was characteristic of a shortlasting- punctually painful stimulus which was promptly answered by a shortlasting increase and decrease of plasma histamine (the histamine injection type as we have called it in trial 3). The increase was up to $3 \mathrm{ng} \cdot \mathrm{ml}^{-1}$, more than 10-times the level of the base-line and occurred with a certain incidence, as expected from the complexity of stress. However, 5 of 11 patients reacted - a considerable proportion of patients. The increase of histamine was accompanied by an increase of both epinephrine and norepinephrine - but not in all and not always in the same patients. Histamine release in patients without catecholamine release may indicate the neuro-inflammatory type of release from mast cells in the peritoneal connective tissue.

During the removal of the gallbladder from the liver bed the increase and elimination of histamine

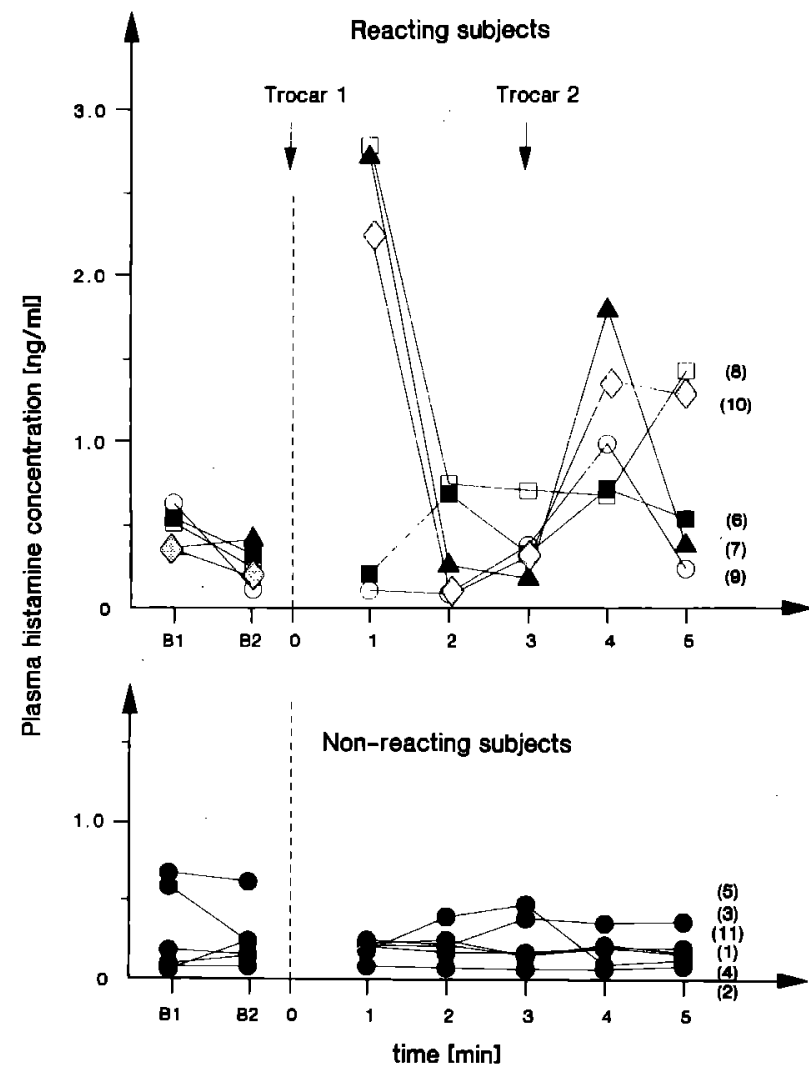

Fig. 9. - Histamine release in the phase of trocar placement in laparoscopic cholecystectomy.

Single values obtained from individual patients. Each patient has his specific graphical sign. Reacting subjects and nonresponders are separated by the criterion of increases in plasma histamine by more than $3 \mathrm{SD}$ of the variation of the histamine assay.

was lower than in the trocar phase (fig. 10). The longlasting elevation of plasma histamine points to a continuing trauma with cytotoxic release due to stopping haemorrhage by coagulation, especially in the second half of gallbladder dissection. The role of cytokines in augmenting the response cannot be ruled out for the second peak since they are certainly produced by peritoneal macrophages in the course of preparation in the Calot's triangle and in the beginning of the dissection. Interesting and in agreement with the proposed mechanisms of histamine release - there was no increase in catecholamines in this phase of operation.

At present, no cardiovascular reactions were observed in the second phase of operation despite plasma histamine levels of $4 \mathrm{ng} \cdot \mathrm{ml}^{-1}$ which after i.v. histamine injection are always associated with at least tachycardia. The reasons for this inconsistent finding are not clear, but it is at present impossible to associate any judgement (unwanted, beneficial) with intraoperative, cytotoxic histamine release. Only in the reperfu- 


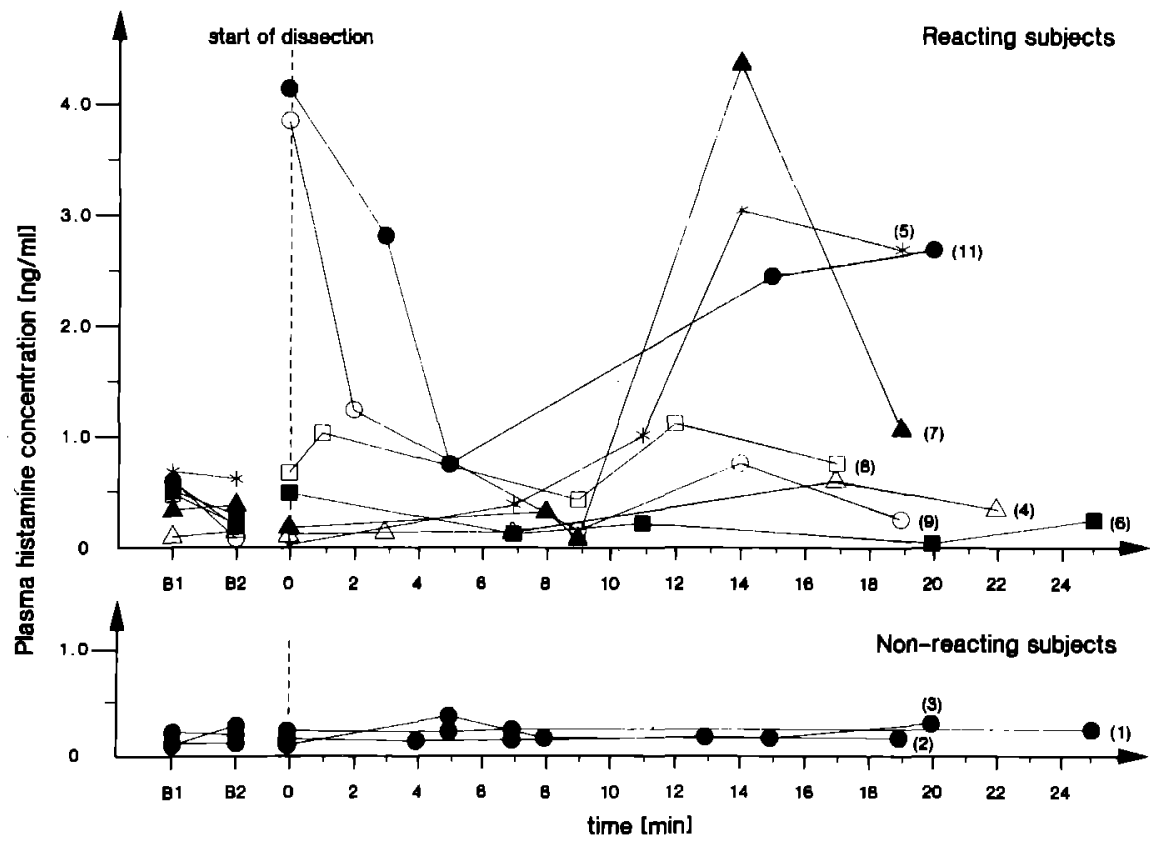

Fig. 10. - Histamine release during retrograde removal of gallbladder from liver bed in laparoscopic cholecystectomy. Single values obtained from individual patients. Each paticnt has his specific graphical sign which corresponds to that in fig. 9 for easy comparison. Reacting subjects and nonresponders are separated by the criteria of increases in plasma histamine by more than $3 \mathrm{SD}$ of the variation of the histamine assay.

sion phase of liver transplantation in pigs such unwanted effects (hypotension) could be demonstrated $[59,60]$.

\section{DISCUSSION ABOUT PERIOPERATIVE HISTAMINE RELEASE : ITS RESTRICTION TO CLASSIFICATION}

Although this article contains a considerable amount of original data, it is not conceived as an experimental, but as an conceptual paper. The classification by means of aetiology in special and clinical epidemiology in general was created to introduce a certain kind of order in a chaos of perioperative findings which were not available before the conduct of the Mainz-Marburg trial with its precise recording of clinical and biochemical phenomena and its small prospective trials which intended to explain the surprising data of this randomized study. In this connection, the data in the plasma substitute phase are really surprising : they should change current opinions about frequency and clinical relevance of drug-induced pseudoallergic reactions.

People may ask why in the last ten years this group has spent so much energy on classifying histamine release in the perioperative period. Indeed, there are now three types of classification :

- 1) along the axis of severity $[63,66]$ : cutaneous, systemic and life-threatening histamine release reactions were distinguished by using methods of clinical judgement and objective medical decision making. This classification has gained a wide recognition and is included in reviews [16, $41,51,86]$ and textbooks [23] of anaesthesiology and allergology. It combined clinical signs with plasma histamine levels and was successful in the Mainz-Marburg trial in the phase of plasma substitute and steady state after induction of anaesthesia and before skin incision.

- 2) along the axis of differential diagnoses $[71,75]$ : it depends on measurement of mediators and assessing clinical signs and has the classes : no reactions, histamine release without reaction, histamine release reactions, cardiovascular reactions, and other reactions including pseudoallergic reactions without histamine release (but that of leukotrienes, etc.).

- 3) along the axis of aetiology of histamine release (this article) : drug-induced allergic, druginduced pseudoallergic, neuro-endocrine, neuroinflammatory, cytotoxic and local, cytokineinduced histamine release.

All three classifications have only one aim : to evaluate the clinical relevance of perioperative histamine release and to test and demonstrate where an intervention with histamine antagonists and possibly also agonists (impromidine, arpromidine) [3] is necessary. As with other kinds of preoperative prophylaxis, such as antithrombotic, antiinfec- 
tious, and stress-ulcer preventing, it is also not easy to define which patients should and who should not receive such drugs or measures for prevention of histamine release reactions [78]. Finding groups and subgroups is a general aim in our time which wants to tailor exactly treatments to individual patients.

However, an expected clinical relevance of mediator release (not only of histamine) in the perioperative period is also derived from our pathophysiological understanding.

1) For histamine, RöHer and Lorenz [94] formulated : "Even if it is difficult to show in a single case, histamine release may be important via a delayed effect for postoperative thromboembolic complications, for after-effects of cardiac arrhythmias, for manifestation of a myocardial infarction or for the development of ARDS and stress ulcer. The primarily healthy patient may have sufficient reserves for compensation of mediator release, but the patient at risk is much more endangered ».

2) For the modification of the stress response, KEHLET [42] formulated: «Concern about detrimental effects of surgery such as myocardial infarction, pulmonary complications, thromboembolism, impaired immunofunction and convalescence with fatigue, inability to work etc., all of which may not be considered as a result of imperfections in surgical technique, has therefore led to studies of possible blocking of the trauma response. This is based upon the hypothesis that, by inhibiting the surgically induced metabolic response, the increased demands on various organs

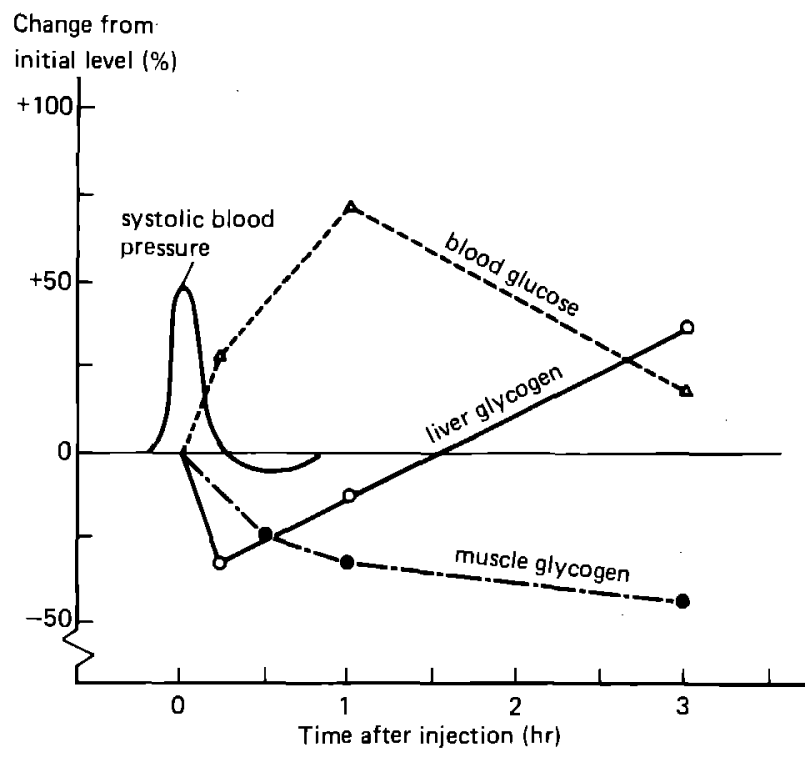

Fig. $11 .-$ The relatively slow effect of epinephrine $(0.2 \mathrm{mg}$. $\mathrm{kg}^{-1}$ body weight) on the blood glucose and tissue glycogen levels of the normal rat, as compared with quick response of the cardiovascular system to this hormone. From STrand [104]. may be consequently diminished and that this may be beneficial by lowering morbidity in high-risk surgical patients " .

3) In agreement with such pathophysiological considerations is the general finding on the different duration of the effects of catecholamine release, if the cardiovascular system, or metabolic changes associated with them are considered (fig. 11) [104].

Acknowledgements: The authors of this conceptual article have to thank all members of the advisory group of the study (C. Ohmann, H. Immich, M. Healy, H.D. Röher, J. MCPeek, J. Moss, J.W. Black, D. ReHN, H.J. Bruer and M. GüNTHER), all members of the coordinator group and of the executive group of the Mainz-Marburg trial and of the 3 prospective studies. In addition, the support by W. KRACK and $C$. OPPER in the study group on minimal invasive surgery and the support of grant giving authority (Deutsche Forschungsgemeinschaft) and three companies (Ciba-Geigy Zyma, SK Beecham and Behring) is very appreciated.

\section{REFERENCES}

1. Altura BM, Halevy S. Circulatory shock, histamine, and antihistamines: therapeutic aspects (pp 575-602). In : Handbook of Experimental Pharmacology (18/2) : Histamine II and anti-histaminics. M Rocha E SiLva ed. Springer, Berlin, Heidelberg, New York, 1978.

2. Andrews FM, Withey SB. Social indicators of wellbeing : Americans' perceptions of life quality. Plenum Press, New York, 1976.

3. Baumann G, Buschauer A, Felix S. Hemodynamic profile of arpromidine and its $F_{2}$-substituted derivatives in comparison to impromidine in congestive heart failure. Agents Actions, Special Conference Issue, C329-C332, 1992.

4. Bischoff SC, Baggiolini M, de Weck AL, Dahinden CA. Interleukin 8-inhibitor and inducer of histamine and leukotriene release in human basophils. Biochem Biophys Res Commun, 179 : 628-633, 1991.

5. Boros M, Kaszaki J, Nagy S. Histamine release during intestinal ischemia-reperfusion : role of iron ions and hydrogen peroxide. Circ Shock, 35: 174-180, 1991.

6. Broide DH, Smith CM, Wasserman SI. Mast cells and pulmonary fibrosis. Identification of a histamine releasing factor in bronchoalveolar lavage fluid. I Immunol, 145: 1838-1844, 1990.

7. Brunner T, de Weck AL, Dahinden CA. Platelet-activating factor induces mediator release by human basophils primed with IL-3, granulocyte-macrophage colony-stimulating factor, or IL-5. J Immunol, 147: 237-242, 1991.

8. Carruthers M, Taggart P, Conway N, Bates D. Validity of plasma-catecholamine estimations. Lancet, ii : 6267,1970 .

9. Chanl A. Role of histamine in the action of neuropeptides and local hormones (pp 521-548). In : Handbook of Experimental Pharmacology (97): Histamine and Histamine Antagonists. B UvNÄs ed. Springer, Berlin, Heidelberg, New York, 1991.

10. De Weck AL. Discussion remark to the paper of Pearce FL. Non-IgE-mediated mast cell stimulation ( $\mathrm{pp}$ 87-92). In : $\mathrm{IgE}$, mast cells and the allergic response. Ciba Foundation Symposium 147, John Wiley \& Sons, Chichester. 1989. 
11. Di PAolo N. Sachil G. Anatomy and physiology of the peritoneal membranc (pp 10-26), In : Contrib Nephrol (84) : Evolution and trends in peritoneal dialysis. LL Scarpioni, S Ballocchi, eds. Karger, Basel, 1990.

12. Dick W, Lorenz W, Heintz D, Sitter H, Doenicke A Histaminfreisetzung bei der Einleitung von Kombinationsnarkosen mit Nalbuphin oder Fentanyl. Anaesthesist, 41 : 239-247, 1992.

13. Duda D, Lorenz W, Menke H, Rugeles MS, Stinner B, Weber D, Kapp B, Junginger T, Dick W. Histamine release during induction of anaesthesia and preparation for operation in patients undergoing general surgery: Incidence and clinically severe cases. Agents Actions (Special Conference Issue) C149-C154, 1992.

14. Duda D, Lorenz W, Rugeles MS, Menke H, Dick W. Histaminfreisetzung bei Einleitung von Routinenarkosen und Vorbereitung von allgemeinchirurgischen Patienten : Neue Zahlen zur Inzidenz und zu schweren Zwischenfällen bei Tumorpatienten. Anaesthesist, 41 : 706-725, 1992.

15. ENNIS $M$, LoRENZ W. Hypersensitivity reactions induced by anaesthetics and plasma substitutes (pp 457-474). In : Immunotoxicology and Immunopharmacology. JH DEAN ed. Raven-Press, New York, 1985.

16. Fisher MMcD. General pharmacological principles. Adverse reactions. Clin Anaesthesiol, 2 : 451-462, 1984.

17. Fisher MMcD. Direct histamine release in anaesthesia and surgery : unanswered questions. Theor Surg, 3: 145147, 1988.

18. Fong Y, Moldawer Ll, Shires GT, Lowry SF. The biologic characteristics of cytokines and their implication in surgical injury. Surg Gynecol Obstet, 170: 363-378, 1990.

19. Foreman JC. Neuropeptides and the pathogenesis of allergy. Allergy (Copenh). 42: 1-11, 1987.

20. Friedl HP, Till GO, Trentz O, Ward PA. Roles of histamine, complement and xanthine oxidase in thermal injury of skin. Am J Pathol, 135 : 203-217, 1989.

21. Frustorfer B, Pritsch MG, Poitsch MB, Clement HW, Wesemann W. Effects of daytime noise load on the sleepwake-cycle and endocrine pattern in man. III. $24 \mathrm{hrs}$.secretion of free and sulphate-conjugated catecholamines. Int $J$ Neurosci, 43 : 53-62, 1988.

22. Futo J, Kupferberg JP, Moss J. Inhibition of histamine $\mathrm{N}$-methyltransferase (HNMT) in vitro by neuromuscular relaxants. Biochem Pharmacol, 39: 415-420, 1990.

23. Galletly DC, GibBs JM. Anaphylactoid reactions during anaesthesia. In: General anaesthesia. JF NUNN, JE UTting BR BRowN Jr eds. 5 th Edition. Butterworths, London, 1989.

24. Galli SJ. Biology of disease. New insights into " the riddle of the mast cells ": Microenvironmental regulation of mast cell development and phenotypic heterogeneity. Lab Invest, 62 : 5-33, 1990.

25. Goetzl EJ, Chernov-Rogan T, Furuichi K, Goetzl LM, LEE JY, RENOLD F. Neuromodulation of mast cell and basophil function (pp 223-229). In : Mast cell differentiation and heterogeneity. AD Befus et al. eds. Raven Press, New York, 1986.

26. Gordon JR, Galdi SJ. Mast cells as a source of both preformed and immunologically inducible TNF- $\alpha /$ cachectin. Nature, 346: 274-276, 1990.

27. Gordon JR, Galli SJ. Release of both preformed and newly synthesized tumor necrosis factor $\alpha$ (TNF- $\alpha$ )/cachectin by mouse mast cells stimulated via the $F_{c} R I$. A mechanism for the sustained action of mast cell-derived TNF- $\alpha$ during IgE-dependent biological responses. $J$ Exp Med, 174: 103-107, 1991.

28. Grant JA, Alam R, Lett-Brown MA. Histamine-releasing factors and inhibitors: historical perspectives and possible implications in human illness. I Allergy Clin Immunol, 88 : 683-693, 1991
29. Green JB, Johnson CL, Weinstein H. Histamine as a neurotransmitter (pp 319-332). In : Psychopharmacology a generation of progress. MA LiPToN, A DI MAscio, KF Killam eds. Raven Press, New York, 1978.

30. Green JP, Prell GD, Khandelwal JK, Blandina P. Aspects of histamine metabolism. Agents Actions, 22 $1-15,1987$.

31. Guggenheim M. Die biogenen Amine und ihre Bedeutung für die Physiologie und Pathologie des pflanzlichen und tierischen Stoffwechsels (pp 462-463). Karger, Basel, New York, 1951

32. Halter JB, Pflug AE, Porte D. Mechanism of plasma catecholamine increases during surgical stress in man. J Clin Endocrinol Metab, 45 : 936-944, 1977.

33. Hargreaves KM, Dionne RA. Evaluating endogenous mediators of pain and analgesia in clinical studies (pp 579. 597). In : Advances in Pain Research and Therapy (18). M Max, R Portenoy, E' Laska eds. Raven Press, New York, 1991

34. Harle DG, Baldo BA, Fisher MM. Inhibition of histamine-N-methyltransferase by neuromuscular blocking drugs. Agents Actions, 17 : 27-31, 1985.

35. Hirai K, Yamaguchl M, Misaki Y, Takaishi T, Ohta K, Morita Y, ITO K, MIYamoto T. Enhancement of human basophil histamine release by interleukin 5.J Exp Med, 172: $1525-1528,1990$.

36. Hoar PF, Stone JG, Faltas AN, Bendixen HH, Head RJ, Berkowitz BA. Hemodynamic and adrenergic responses to anesthesia and operation for myocardial revascularization. I Thorac Cardiovasc Surg, 80: 242-248, 1980 .

37. Hollenberg MD. Receptor triggering and receptor regulation: structure-activity relationships from the receptor's point of view. J Med Chem, 33 : 1275-1281, 1.990.

38. Hough LB, GLick SD, Su K. A role for histamine and histamine $\mathrm{H}_{2}$-receptors in non-opiate footshock-induced analgesia. Life Sci, 36 : 859-866, 1985.

39. Hougu LB. Cellular localization and possible functions for brain histamine: recent progress. Prog Neurobiol, 30 : 469-505, 1988

40. Kaplan AP, Reddigari S, Baeza M, Kuna P. Histamine releasing factors and cytokine-dependent activation of basophils and mast cells. Adv Immunol, 50 : 237-260, 1991

41. Kazimierczak W, Diamant B. Mechanisms of histamine release in anaphylactic and anaphylactoid reactions. Prog Allergy, 24 : 295-365, 1978.

42. KeHLeT $H$. The stress response to anaesthesia and surgery : release mechanisms and modifying factors. Vasoactive amines. Clin Anaesthesiol, 2 : 315-399, 1984.

43. Khandelwal JK, Hough LB, Green JP. Histamine and some of its metabolites in human body fluids. Klin Wochenschr, 60 : 914-918, 1982.

44. Khandelwal JK, Hough LB, Morrishow AM, Green JP. Measurement of tele-methylhistamine and histamine in human cerebrospinal fluid, urine, and plasma. Agents Actions, 12 : 583-590, 1982.

45. KNIGGE U, WARBERG J. Neuroendocrine functions of histamine. Agents Actions (suppl), 33 : 29-53, 1991.

46. Kuna P, Reddigari SR, KoRnfeld D, Kaplan AP. IL-8 inhibits histamine release from human basophils induced by histamine-releasing factor, connective tissue activating peptide III, and IL-3. J Immunol, 147: 1920-1924, 1991.

47. Kurimoto Y, DE WECK AL, Dahinden CA. Interleukin 3 dependent mediator release in basophils triggered by $\mathrm{C} 5 \mathrm{a}$. $J$ Exp Med, 170 : 467-480, 1989.

48. Kurimoto Y, DE WECK AL, Dahinden CA. The effect of interleukin 3 upon IgE-dependent and IgE-independent basophil degranulation and leukotrienne generation. Eur $J$ Immunol, 21 : 361-368, 1991 
49. Kusche J, Lorenz W, Hesterherg R. The relevance of the diamine oxidase-histamine system for shock development following intestinal ischemia (pp 255-280). In : Animal models for intestinal discase. CJ Preifer ed. CRC Press, Boca Raton, Florida, 1985.

50. Kusche J, Lorenz W, Stahliknecht CD, Richter H, Hesterberg R, Schmal A, Hinterlang E, Weber D, OHMANN C. Intestinal diamine oxidase and histamine release in rabbit mesenteric ischemia. Gastroenterology, 80 : 980-987, 1981.

51. LARSEN R. Lebensbedrohliche Narkosekomplikationen (pp 743-754). In : Anästhesie. R LARSEN ed. Urban \& Schwarzenberg, München, Wien, Baltimore, 1987.

52. LAXENaire MC. Prevention of anaphylactoid reactions. Ann Fr Anesth Réanim, 4: 99-100, 1985.

53. Laxenaire MC, Moneret-Vautrin DA. Le risque allergique en Anesthésie-Réanimation. Collection d'Anesthésiologie et de Réanimation. Vol. 17 (154 p.). Masson, Paris, 1990.

54. Laxenaire MC, Moneret-Vautrin DA. Meeting « New Trends in Anaphylactoid Risk in Anaesthesia. " Nancy (France), 11-12 June 1992. Ann Fr Anesth Réanim, 12: 89-227, 1993.

55. Levi R, Chenouda AA, Trzeciakowski JP, Guo ZG, Aaronson LM, LUSKIND RD, LEE $\mathrm{CH}$. Dysrhythmias caused by histamine release in guinea pig and human hearts. Klin Wochenschr, 60: 965-971, 1982.

56. LEVY JH. Anaphylactic reactions in anaesthesia and intensive care (p 173). Butterworth, Guildford, 1986.

57. LeVy JH, Adelson AA. Effects of vecuronium-induced histamine $\mathrm{N}$-methyltransferase inhibition on cutaneous responses to histamine. Agents Actions (Special Conference Issue) C211-C212, 1992

58. Lorenz W, Reimann HJ, Barth H, Kusche J, Meyer R, Doenicke A, Hutzel M. A sensitive and specific method for the determination of histamine in human whole blood and plasma. Hoppe Seylers Z Physiol Chem, 353 : 911920, 1972.

59. Lorenz W, Boeckl O, Struck E, Hell E, Zimmermann G, Reimann HJ, Tauber R, Scheffer B. Significance and causes of histamine release during orthotopic homologous liver transplantation in the pig. Agents Actions, 3: 2-11, 1973.

60. Lorenz W, Hell E, Boeckl O, Reimann HJ, Zimmermann G, Seidel W, Laszcz M, Uhlig $R$. Histamine release during orthotopic homologous liver transplantation in pigs. Eur Surg Res, 5: 11-20, 1973.

61. Lorenz W, Seidel A, Doenicke A, Tauber R, Reimann HJ, Uhlig R, Mann G, Dormann P, Schmal A, Häfner $G$, HamelmanN H. Elevated plasma histamine concentrations in surgery : causes and clinical significance. Klin Wochenschr, 52: 419-425, 1974.

62. Lorenz W, Thermann $M$, Messmer $\mathrm{K}$, Schmal A Dormann P, Kusche J, Barth H, Tauber R, Hutzel M, MANN G, UhLIG R. Evaluation of histamine elimination curves in plasma and whole blood of several circulatory regions: a method for studying kinetics of histamine release in the whole animal. Agents Actions, $4: 336-356$, 1974.

63. Lorenz W. Histamine release in man. Agents Actions, 5 : $402-416,1975$

64. Lorenz W, Doenicke A, Schöning B. Neugebauer E. The role of histamine in adverse reactions to intravenous agents (pp 169-238). In : Adverse reactions of anaesthetic drugs. A Thornton ed. Elsevier/North-Holland Biomedical Press, 1981.

65. Lorenz W, Doenicke A, Schöning B, Karges H, SCHMAL A. Incidence and mechanisms of adverse reactions to polypeptides in man and $\operatorname{dog}$ (pp 207-234). In : Devolop biol Standard. (48) : Joint WHO/IABS Symposium on the standardization of albumin. plasma substitutes and plasmapheresis, Geneval, 1980. W Hennessen ed. Karger, Basel, 1981

66. Lorenz W, Doenicke A, Schöning B. Oimann C, Grote $B$, Neugebauer E. Definition and classification of the histamine-relcase response to drugs in anaesthesia and surgery: Studies in the conscious human subject. Klin Wochenschr, 60 : 896-913, 1982.

67. Lorenz W, Röher HD, Doenicke A, Ohmann C. Histamine release in anaesthesia and surgery: a new method to evaluate its clinical significance with several types of causal relationship. Clin Anaesthesiol, 2 : 403-426, 1984.

68. LoREnz W, DoEnicke A. $\mathrm{H}_{1}-+\mathrm{H}_{2}$-blockade : a prophylactic principle in anaesthesia und surgery against histamine-release responses of any degree of severity. $N$ Engl Reg Allergy Proc, Part I : 6 : 37-57, 1985; Part II : 6: 174-194, 1985

69. LoRenz W, Doenicke A. Histamine release induced by anaesthetic drugs or their solvents : nonspecific or specific? Ann Fr Anesth Réanim, 4 : 115-123, 1985.

70. LoRenz W, Doenicke A, Dietz W. Release of histamine by $\mathrm{H}_{2}$-receptor antagonists. Lancet, ii : 1098, 1987.

71. Lorenz W, Dick W, Junginger T, Ohmann C, Ennis M, Immich H, McPeek B, Dietz W, Weber D. Members of the Trial Group Mainz/Marburg. Induction of anaesthesia and perioperative risk: influence of antihistamine $\mathrm{H}_{1}-+\mathrm{H}_{2}$-prophylaxis and volume substitution with Haemaccel - 35 on cardiovascular and respiratory disturbances and histamine release - protocol of a controlled clinical trial. Theor Surg, 3: 55-77, 1988.

72. Lorenz W, Ennis M, Doenicke A, Dick W. Perioperative uses of histamine antagonists. J Clin Anesth, 2 : 345360, 1990 .

73. Lorenz W, Neugebauer E. Current techniques of histamine determination. Fluorometric assays (pp 9-30). In Handbook of Experimental Pharmacology (97). B UVNÄs ed. Springer, Berlin, Heidelberg, 1991

74. Lorenz W, Neugebauer E, Uvnäs B, Beaven MA, Ennis M, Granerus G, Green JP Keyzer JJ, McBride PT, Mannaioni PF, Pearce Fl, Watkins J. Munich consensus development conference on histamine determination (pp 81-92). In: Handbook of Experimental Pharmacology (97). B UvNÄs ed. Springer, Berlin, Heidelberg, 1991 .

75. Lorenz W, Sitter H, Stinner B, Duda D, Kapp B, Gstrein B, Dietz W, Doenicke A, Dick W. Controlled clinical trials and cross-sectional studies with plasma histamine measurements and histamine receptor antagonists: solving the problem of preoperative $\mathrm{H}_{1^{-}}+\mathrm{H}_{2}$-prophylaxis by asking new questions (pp 197-230). In : Agents Actions (suppl) (33) : New perspectives on histamine research. $\mathrm{H}$ Timmermann, H Goot eds. Birkhäuser, Basel, 1991.

76. Lorenz W, Thon K, Stöltzing H, Neugebauer E, LindLAR R Sattler J, Werer D. Histamine and the stomach : chemical histamine assays. Scand $J$ Gastroenterol, 26 (suppl) : 9-25, 1991.

77. Lorenz W, Kubo K, Stinner B, Sitter H Hasse C, Dietz W, Schmal A, Krack W. Studies on the effectiveness of $\mathbf{H}_{1^{-}}+\mathrm{H}_{2}$-antagonist combinations in preventing life-threatening anaphylactoid reactions in anaesthesia and surgery: Problems with selecting the animal model from clinical data and with " equi-effective» doses. Agents Actions (Special Conference Issue) C231-C237, 1992.

78. Lorenz W, Stinner B, Dietz W, Koller M, Rothmund M, Dıck W. Problem solving strategies with biomedical and clinimetric components : the case of perioperative $\mathrm{H}_{1^{-}}$ $+\mathrm{H}_{2}$-prophylaxis. Agents Actions (Special Conference Issue) C213-C218, 1992.

79. Mannaioni PF, Fantozzi R, Gianella E, Masini E. Pathophysiological significance of the distribution of histamine receptor sub-types : a proposed dual role for histamine in inflammation and type I hypersensitivity reactions. Agents Actions, 24 : 26-34, 1988 
Sil. Mannaioni PF, Masini E. The release of histamine by free radicals. Free Radical Biol Med, 5 : 177-197, 1988.

81. Merget RD, Maurer AB, Koch U, Ganser A, Otimann OG, Schulzewerninghaus $G$, Seipelt $G$, Zachgo $W$, Hoelzer D, Meifr-Sydow J. Histamine release fron basophils after in vivo application of recombinant human interleukin-3 in man. Int Arch Allergy Appl Immunol, 92 : 366-374, 1990.

82. Morse DR, Martin J, Moshonov J. Psychosomatically induced death : relative to stress, hypnosis, mind control, and voodoo: review and possible mechanisms. Stress Med, $7: 213-232,1991$

83. Moss J, Rosow CE. Histaminc release by narcotics and muscle relaxants in humans. Anesthesiology, $59: 330-339$, 1983

84. Moss J. Role of histamine in adverse reactions in the operating room (pp 1-7). In : Annual Refresher Course Lectures. American Society of Anesthesiologists, 1991

85. Moss.J. The impact of histamine research on clinical anesthesia and surgery. Agents Actions (Special Conference Issue) C135-C148, 1992.

86. OwEN DAA. Physiology and pharmacology of histamine : cardiovascular studies in man. Vasoactive amines. Clin Anaesthesiol, 2 : 383-401, 1984.

87. Pearce FL. Non-IgE-mediated mast cell stimulation (pp 75-92). In : IgE, mast cells and the allergic response. Ciba Foundation Symposium 147. John Wiley \& Sons, Chichester, 1989

88. Pedersen M, Permin H, Bendtzen K, Norn S. Cytokineinduced release of histamine from basophil leukocytes from AIDS patients. Agents Actions, 30 : 294-296, 1990.

89. Pluto R, Bürger P, Weicker H. The physiological variability of catecholamine levels in plasma. Klin Wochenschr, 64 : 625-632, 1986

90. RING J, Pseudoallergische Arzneimittelreaktionen : Überlegungen zur Pathophysiologie. Klinik und Diagnose am Beispiel von Röntgenkontrastmitteln und Lokalanästhesie. Allergologie, 8 : 342-350, 1985.

91. RoIzen MF, Moss J, Henry DP, Kopin IJ. Effects of halothane on plasma catecholamines. Anesthesiology, 41 : 432-439, 1974.

92. Roizen MF, Horrigan RW, Frazer BM. Anesthetic doses blocking adrenergic (stress) and cardiovascular responses to incision - MAC BAR. Anesthesiology, 54 : 390-398, 1981 .

93. Röher HD, Lorenz W, Lennartz H, Kusche J, Dietz W, Gerdes G, Parkin JV. Plasma histamine levels in patients in the course of several standard operations: influence of anaesthesia, surgical trauma and blood transfusion. Klin Wochenschr, 60 : 926-934, 1982.

94. RöHer HD, LoRENz W. Histaminfreisetzung in der Chirurgie. Histaminfreisetzung bei Standardoperationen : Überlegungen zur klinischen Relevanz (pp 165-175). In : Histamin und Histamin-Rezeptor-Antagonisten. A DoENiCKE, W LoRENz eds. Springer-Verlag, Berlin, Heidelberg, 1985

95. Russeli. WJ, Morris RG, Frewin DB, Drew. SE. Changes in plasma catecholamine concentrations during endotracheal intubation. Br J Anaesth, 53 : 837-839, 1981.

96. Sattler J, Lorenz W, Schröder D, Klinger A, KlaG J, Glaser $K$. Dennhardt $R$. Histamine release in the course of elective conventional cholecystectomy in aged patients : Problems in defining release in relation to speci- fic intraoperative events. Agents Actions (Special Conference Issue) (155-161, 1992

97. Scilauer. The mast cell (pp 1-64). In : Veröffentlichungen aus der morphologischen Pathologie. F Buchner, W Giese eds. G Fischer, Stuttgart, 1964.

98. SChäfer U, Lindlar R, Opper C, KNoch M, Lorenz W, Rothmund $M$. Tissue trauma in minimal invasive surgery : plasma histaminc and plasma catecholamines as parameters for discrimination of local tissue trauma and general stress reaction in laparoscopic cholecystectomy in patients. Langenbecks Arch Chir Suppl Chir Forum, 181$185,1992$.

99. Sitter H, Lorenz W. Doenicke A. The clinical and biological signs of histamine release during induction of anaesthesia and preparation of the surgical patient: A farewall party for the classical manifestations of anaphylaxis. Agents Actions (Special Conference Issue) C219. C230, 1992.

100. Stanley TH, Berman L, Green O, Robertson DH RoIzEN MF. Fentanyl-oxygen anesthesia for coronary artery surgery: Plasma catecholamine and cortisol responses. Anesthesiology, 51 : S139, 1979.

101. Stellato C, Casolaro V, Ciccarelli A, Mastronardi P. Mazzarella B, Marone G. General anaesthetics induce only histamine release selectively from human mast cells. Br J Anaesth, 67 : 751-758, 1991.

102. Stinner B, Lorenz W, Duda D, Menke H, Kapp B, Dietz W. Serial histamine release in the perioperative period: specific reaction to medical treatment or common response to stress ? Langenbecks Arch Chir Suppl Chir Forum, 359-364, 1991.

103. Stinner B, Hasse C, Lorenz W, Koller M, Opper C, RothMund M. Histamine as a stress hormone : demonstration of a new release pathway with relevance in the perioperative period. Langenbecks Arch Chir Suppl Chir Forum, 425-429, 1992.

104. Strand FL. Physiology. A regulatory systems approach. (p 407). 2nd Ed. Macmillan, New York, 1983.

105. Suttmann H. Doenicke A, Lorenz W, Ennis M, Müller OA, Dorow R, Ackenheil M. Is perioperative stress a real surgical phenomenon or merely a drug-induced effect? Theor Surg, 1 : 119-135, 1986.

106. UVNäs B, ABorg $C H$, Lyssarides L, DANIElson LG Intracellular ion exchange between cytoplasmic potassium and granule histamine, an integrated link in the histamine release machinery of mast cells. Acta Physiol Scand, 136 $309-320,1989$.

107. van Overveld FJ, Jorens G, Rampart M, de Backer W, VermeIre PA. Tumour necrosis factor stimulates human skin mast cells to release histamine and tryptase. Clin Exp Allergy, 21 : 711-714, 1991

108. Ward MM, MefFord IN, Parker SD, Chesney MA, Taylor CB, Keegan DL, Barchas JD. Epinephrine and norepinephrine responses in continuously collected human plasma to a series of stressors. Psych Med, 45: 471-486 1983.

109. Watkins J, Levy CJ. Guide to immediate anaesthetic reactions (pp 1-128). Butterworths, London, 1988.

110. WERSHIL BK, Galli SJ. An approach for analyzing the role of mast cells in inmunotoxicological processes and other biological responses (pp 49-82). In: The role of mast cells. DS Newcome, NR Rose, JC Bloom eds. Raven Press, New York, 1992. 
ABSTRACT : As a consequence of the performance of a randomized controlled clinical trial on perioperative histamine release and cardiovascular and respiratory disturbances, several types of increases in plasmal histamine had to be distinguished instead of only two which existed at the beginning of the study: druginduced allergic and pseudoallergic reactions. First of all, the now classification by aetiology (clinical cpidemiology) was derived from a metaanalysis (secondary analysis) of the most recent literature. According to that histamine release in the perioperative period has several, different causes and is involved in several, different disease manifestations. A clear distinction (classification), however, is necessary if histamine relcase as an unwanted (adverse) effect has to bc recognized, value judged according to its clinical relevance and therefore also prevented by histamine antagonists. Histamine release by neuro-endocrinc and neuro-inflammatory mechanisms, cytotoxic histamine relcasc and local, cytokine induced histamine release have been distinguished from pseudoallergic histamine release, but its functions are not yet clear. It has been analysed in prospective trials which used special clinical situations as models : patients on a normal ward or before and during upper GI endoscopy without premedication, but also in specilic phases of laparoscopic cholecystectomy (trocar phase and dissection phase). Their existence in the clinical reality is now very likely, but new trials must investigate the pathophysiological effects such as in metabolism, coagulation, pulmonary haemodynamics (shunt volume) and gastric acid secretion. Histamine release by pseudoallergic mechanisms, however, was identified in the very vulnerable post-induction phase of anaesthesia up to skin incision. Its incidence was much higher than ever expected and its clinical relevance was demonstrated by the severity of reactions and the intervention strategies of the anaesthetists who were blinded concerning the type of the plasma substitute given and the prophylaxis with antihistamines. Pseudoallergic histamine rclease was clearly unwanted (adverse). Its occurence in the other phases of anaesthesia has to be further evaluated in the tedious procedure of data analysis of the Mainz-Marburg-trial. The overall incidence of histamine release in the trial was so incredibly high (72\% of all patients, some of them with up to 4 episodes of histamine release) that a distinction between pseudoallergic (unwanted) and other types of histamine release (possibly less unwanted or even beneficial) is urgently needed. In the phase of steady state (maintenance) of anaesthesia the $\mathrm{H}_{1^{-}}+\mathbf{H}_{2}$-prophylaxis was highly effective. Further analysis must show whether this is also the case during the phases of induction of anaesthesia. Many of the pseudoallergic histamine release reactions (72\%) occur without cutaneous signs - even with plasma histamine levels of $12 \mathrm{ng} \cdot \mathrm{ml}^{-1}$, i.e. in the range of usually lifethreatening reactions. The clinical picture of these reactions has to be revised. Since in the case of haemodynamic instability alone the anaesthetist cannot distinguish between histamine-induced reactions and cardiovascular reactions based on other mechanisms, a considerable underreporting of the reactions is fully understandable. Plasma histamine assays are necessary under strict quality control to create awareness of this considerable clinical problem. If that is understood the questions of antihistamines : yes or no ? to whom? at which time? and which drugs and dose? will be asked in a different way than hitherto. 